\title{
CORRUPÇÃO E SUAS CONSEQUÊNCIAS NEFASTAS: 0 Controle Externo Preventivo e Meios Alternativos Como Mecanismo de Combate
}

\section{Dirceu Pereira Siqueira}

Pós-doutor em Direito pela Faculdade de Direito da Universidade de Coimbra (Portugal), doutor e mestre em Direito Constitucional pela Instituição Toledo de Ensino - ITE/Bauru, especialista Lato Sensu em Direito Civil e Processual Civil pelo Centro Universitário de Rio Preto, Pesquisador Bolsista - Modalidade Produtividade em Pesquisa para Doutor (PPD) do Instituto Cesumar de Ciência, Tecnologia e Inovação (Iceti), professor permanente do Programa de Mestrado em Direito do Centro Universitário Cesumar (UniCesumar), e nos cursos de Graduação em Direito da Universidade de Araraquara (Uniara), do Centro Universitário Unifafibe (Unifafibe) e do Centro Universitário da Fundação Educacional de Barretos (Unifeb), professor convidado do Programa do Programa de Mestrado em "Gestão Estratégica de Empresas - Master Of Science in Administrative Studies (MSAS)" - Disciplina "Ética e Legislação" University Missouri State - EUA, consultor jurídico, parecerista, advogado. dpsiqueira@uol.com.br

\section{André Vinícius Rosolen}

Mestre em Ciências Jurídicas pelo Centro Universitário de Maringá (Unicersumar); especialista em Direito Constitucional pelo Instituto de Direito Constitucional e Cidadania; advogado. andre.rosolen@hotmail.com

Recebido em: 3/4/2017

Aceito em: 9/5/2017

\section{Resumo}

0 presente trabalho versará sobre o controle externo preventivo desempenhado pelo Tribunal de Contas, pelo Ministério Público e pelos cidadãos e sociedade civil organizada sobre as atividades da Administração Pública brasileira, como meio alternativo de resolução de conflitos judiciais sob a perspectiva do combate à corrupção. Os sistemas preventivos de controle (interno e externo) das atividades da Administração Pública fortalecem os mecanismos de prevenção da corrupção na ordem jurídica, mitigando a possibilidade da prática de atos ilícitos, desvios de finalidades, dilapidação do patrimônio público, malversação dos recursos públicos e a utilização indevida dos bens públicos para satisfazer interesses particulares. Os métodos de pesquisa utilizados foram os bibliográficos e jurisprudenciais, com o objetivo de analisar as atribuições fiscalizatórias dos órgãos públicos e da população, bem como dos mecanismos preventivos e alternativos de controle no combate à corrupção. 
Os benefícios da adoção do controle externo preventivo consistem na racionalização e celeridade do processo, na efetividade e utilidade das decisões administrativas, no auxílio da prévia identificação dos responsáveis e diagnósticos das áreas de riscos da corrupção; na possibilidade de decretação de indisponibilidade de bens e o ressarcimento dos danos causados ao erário de forma administrativa, sem, contudo, restringir o acesso à Justiça quando os instrumentos de controle se tornarem insuficientes e ineficazes para evitar os atos de corrupção. As proposições do controle preventivo como forma de combate à corrupção consistem na elaboração e adoção de um conjunto de medidas extrajudiciais destinadas ao aprimoramento dos sistemas de controle externo dos atos da Administração Pública, como meio alternativo do ajuizamento de ações judiciais.

\section{Palavras-chave}

Controle externo preventivo da administração pública. Tribunal de Contas. Ministério Público. Controle popular. Combate à corrupção e meios alternativos de solução de conflito.

\section{CORRUPTION AND ITS NEFAST CONSEQUENCES: PREVENTIVE EXTERNAL CONTROL AND ALTERNATIVE MEANS AS A COMBAT MECHANISM}

\section{Abstract}

This work will focus on preventive external control performed by the Court, the public prosecutor and by citizens and organized civil society on the activities of the Brazilian Public Administration, as an alternative means of resolving legal conflicts from the perspective of the fight against corruption. Preventive control systems (internal and external) of the activities of the Public Administration strengthen the mechanisms for preventing corruption in the legal system, mitigating the possibility of illicit behavior, purposes of diversion, squandering of public assets, public funds embezzlement and misuse of public goods to satisfy particular interests. The research methods used were bibliographic and jurisprudence in order to analyze the fiscalizatórias responsibilities of government agencies and elsewhere, as well as preventive and alternative control mechanisms to combat corruption. The benefits of adopting preventive external controls consist of the rationalization and process speed, the effectiveness and utility of administrative decisions, aiding in the early identification of those responsible and diagnostics in the areas of corruption risk; the possibility of declaration of unavailability of goods and compensation for damage caused to the Treasury administratively, without, however, restrict access to justice when the control instruments become inadequate and ineffective to prevent acts of corruption. The propositions of preventive control as a way of combating corruption consists in the elaboration and adoption of a set of voluntary measures aimed at improvement of external control systems of the acts of the Public Administration, as an alternative means of filing lawsuits.

\section{Keywords}

External Control Preventive Public Administration. Audit Office. Public Ministry. Popular control. Combating Corruption and alternative means of conflict resolution.

\section{Sumário}

1 Introdução. 20 Controle da Administração Pública brasileira. 2.1 Classificação do controle da Administração Pública brasileira. 2.2 Controle externo pelo Tribunal de Contas. 2.3 Controle externo pelo Ministério Público. 2.4 Controle externo pelo cidadão e sociedade civil organizada (controle popular). 3 Conclusão. 4 Referências 


\section{INTRODUÇÃO}

O controle da corrupção poderá ser desempenhado pelos sistemas de controle interno e externo dos órgãos públicos e dos poderes do Estado (controles estatais), assim como pelos mecanismos de controle externo preventivo ou sucessivo outorgados pela legislaçáo brasileira aos cidadãos e à sociedade civil organizada (controle social).

Os mecanismos de controle da Administração Pública e a prerrogativa para o exercício de fiscalização conferida aos órgãos públicos e aos cidadãos são justificados para assegurar a integridade da conduta, a lisura das funçôes públicas e a proteção dos direitos fundamentais diante das violaçóes e abusos perpetrados pelos agentes públicos e particulares.

O objeto do trabalho consiste na apresentação e na análise dos mecanismos preventivos de controle externo previstos na ordem jurídica outorgados aos órgãos dos Tribunais de Contas, à instituição do Ministério Público e aos cidadãos e à sociedade civil organizada, ou seja, visa a discorrer sobre os instrumentos externos preventivos de fiscalização dos atos administrativos como meio alternativo ao ajuizamento de açôes judiciais, mediante a resoluçáo preventiva do fenômeno da corrupção na esfera pública.

Os motivos e a justificativa para adoção dos mecanismos preventivos do controle externo estão associados com a superação do tradicional modelo processual moroso que acaba por favorecer os corruptos pela lentidão do julgamento das açôes; com a incidência de prazos prescricionais que serve de estímulo para prática da corrupção; com a falta de criação de órgãos e Varas especializados no combate à corrupçáo para evitar as ilegalidades e nulidades do processo, entre outros obstáculos e percalços existentes no ordenamento jurídico.

Por tais razóes, o sistema preventivo de controle externo desempenhado pelos Tribunais de Contas, pelo Ministério Público e pelos cidadãos sobre a atuação da Administração Pública representa mecanismo jurídico adequado no combate à corrupção e como meio alternativo de resolução dos conflitos judiciais, uma vez que contribuem com celeridade para a resoluçáo dos litígios e o racionamento de processos judiciais, sobretudo para impedir as ilegalidades e o abuso de poder antes da consolidação do ato administrativo e dos danos causados ao erário. 


\section{CONTROLE DA ADMINISTRAÇÃO PÚBLICA BRASILEIRA}

A identificação das áreas de vulnerabilidades e dos riscos da corrupção na Administração Pública requer a elaboração de diagnósticos normativos e morais de controle sobre suas atividades. Outro desafio a vencer consiste na criação de sistemas imunológicos que protegem a sociedade dos atos de corrupção, da decadência institucional e da dissolução da coesão social (SPECK, 2002, p. 21-22).

A acepção controle deriva do francês "contrôler" que designa o ato de dirigir qualquer serviço mediante a fiscalização ou orientação de modo mais conveniente (MICHAELIS, 2013, p. 226). Desse modo, o controle consiste no ato ou efeito de controlar - monitorar, fiscalizar ou examinar - de forma minuciosa algo, mediante a obediência a determinadas normas (HOUAISS; VILLAR, 2007, p. 825). ${ }^{1}$

Os primeiros sistemas de controle da Administração Pública surgiram sob o aspecto financeiro com o início da fase embrionária da organização e estruturação do Estado durante o período greco-romano, uma vez que as instituiçóes estavam encarregadas de realizar o controle sobre o recebimento dos tributos e sobre o pagamento das despesas com a organizaçáo dos serviços públicos e o atendimento dos cidadãos (CITADINI, 1995, p. 11).

No período moderno, o controle das atividades do poder público consistia na verificação das ilegalidades perpetradas pelos agentes estatais e na fiscalização dos abusos de poder em virtude da liberdade do cidadão. Náo obstante, o Estado Constitucional consagrou os direitos fundamentais para proteger os indivíduos contra os abusos praticados pelos detentores do poder estatal, bem como estabe-

1 Os meios de controle foram aplicados na técnica comercial para indicar a inspeção e o exame que se processa nos papéis ou nas operaçóes que eram registradas nos estabelecimentos comerciais, ou seja, consistia na fiscalizaçáo organizada dentro do estabelecimento comercial para controlar todos os negócios e operaçóes realizadas, por meio das conferências imediatas ou registros especiais, com as respectivas anotaçóes e registros em livros (SILVA, 2014, p. 386). Posteriormente, com o advento do Estado Constitucional ao instituir a separação dos poderes do Estado (Legislativo, Executivo e Judiciário), houve a necessidade de criação de mecanismos de controle de um poder sobre o outro para assegurar o cumprimento da norma fundamental e de impedir abusos de poder. Na modernidade, o controle sobre os poderes do Estado foi protagonizado por Montesquieu ao defender a instituição do sistema de freios e contrapesos ou controle do poder pelo poder (checks and balances). Os poderes Legislativo, Executivo e Judiciário exercem parcela da soberania do Estado, o que justifica a criaçáo de mecanismos de controle sobre as atividades do poder público para evitar abusos e desvios de condutas. 
leceu limites sobre as atividades e o modo de exercício por meio da consagração da separação dos poderes do Estado (Legislativo, Executivo e Judiciário), a fim de preservar o equilíbrio entre os poderes e possibilitar o controle de um sobre o outro.

A Administração Pública é uma pessoa jurídica de Direito Público dotada de personalidade jurídica própria pertencente à organização político-administrativa do Estado, com a função de executar atividades administrativas e a prestação dos serviços públicos em busca do interesse público coletivo e o bem comum. No Brasil, a Administração Pública encontra-se subdividida em Administração Pública direta (União, Estados, Municípios e Distrito Federal) e a Administração Pública indireta (autarquias, fundaçóes públicas, empresas públicas e as sociedades de economia mista).

O Estado é administrado por agentes públicos - seres humanos - que manifestam suas vontades por delegação popular ou sistema de representação, com pretexto de atender ao interesse público e de satisfazer o bem comum. Os detentores do poder do Estado, todavia, na condição de responsáveis pela administração dos bens e dos recursos públicos também estáo sujeitos à falibilidade humana, ao cometimento de erros e desvios de condutas, tonando indispensável a elaboração de mecanismos de controle da Administração Pública para prevenir, revisar e corrigir eventuais ilegalidades (MARINELA, 2011, p. 981).

A existência de órgãos de controle para averiguação dos atos praticados pelos agentes da Administração Pública representa uma característica do Estado contemporâneo, ${ }^{2}$ uma vez que decorre da própria organização sistematizada dos poderes, do sistema de eleiçôes temporárias para os representantes eleitos pelo povo, da responsabilidade pelos atos praticados no exercício das suas funções, do dever de prestar contas e da proteção dos direitos e garantias fundamentais (CITADINI, 1995, p. 11).

2 Os mecanismos de controle dos atos da Administração Pública são frutos do Estado de Direito, uma vez que exercem a tarefa de verificar se o ato administrativo praticado pelo agente público estava em conformidade ou não com a legislação e o interesse público. Por outro lado, nos Estados tiranos e déspotas não existem quaisquer tipos de controle sobre os atos praticados por seus dirigentes, em razão da ausência de transparência, a preponderância da vontade parcial dos governantes e a submissão forçada dos governados (MARTINS JÚNIOR, 2009, p. 313). 
O Estado Constitucional brasileiro está assentado no Estado Democrático de Direito, adotando a República como forma de governo, a Federação como forma de Estado e a democracia como regime de governo. A norma constitucional assegura o exercício do poder político ao povo brasileiro por meio dos seus representantes eleitos, razão pela qual estão submetidos ao dever de prestar contas sobre os atos administrativos praticados e à previsão de responsabilidade pelos desvios de condutas e ilegalidades (artigo 70, parágrafo único, $\mathrm{CF} / 88$ ).

O controle da esfera pública está relacionado com o Regime Republicano ${ }^{3}$ por que o Estado pertence ao povo brasileiro e não aos representantes, que são apenas meros delegatários do poder. Com isso, surge a necessidade da criaçáo de mecanismos de controle, fiscalização e de vigilância que um órgão exerce sobre a conduta funcional dos agentes públicos para prevenir a prática de irregularidades e para revisar ou corrigir as ilegalidades causadas pelos desvios de finalidade e abusos de poder (MARINELA, 2011, p. 981).

O controle perante a Administração Pública consiste na verificação se os atos e as atividades do governo atenderam à finalidade pública almejada e se estão em consonância com os objetivos, o interesse público e as normas jurídicas aplicáveis ao poder público (CONTROLADORIA..., 2012, p. 16). A fiscalização dos atos da Administração Pública tem fundamento constitucional extraído no princípio do regime republicano, estando presente no dever de prestar contas para a sociedade e na previsão de responsabilidade pelos atos praticados.

Os deveres do regime republicano estão fundamentados no dever de o agente público agir com transparência, na obrigação de prestar de contas à sociedade e na previsão de responsabilidade dos agentes pelos atos praticados no exercício das funçôes públicas. Os princípios republicanos são diretrizes hermenêuticas e balizas de interpretação para aplicação dos princípios da Administração Pública (regime jurídico-administrativo), sendo normas estruturantes para realização do interesse

\footnotetext{
3 Oportuna lição de Dalmo de Abreu Dallari, que apresenta as principais características do regime republicano que perduram desde o século 17: a) temporariedade: exercício do mandato pelo chefe do governo com prazo de duração predeterminado, estabelecendo a proibiçáo de eleiçóes sucessivas com a finalidade de evitar a permanência do indivíduo no poder; b) eletividade: o governante será eleito pelo povo, com a finalidade de evitar a sucessão hereditária ou impedir que o povo participe do processo de escolha do seu representante; c) responsabilidade: o chefe de governo é politicamente responsável pelos atos de governo, devendo prestar contas de sua orientaçáo política diretamente ao povo ou ao órgão de representação popular (DALLARI, 2013, p. 227-228).
} 
público e concretização do direito fundamental à moralidade e à proteção do patrimônio público, diante dos abusos e lesóes perpetradas pelos agentes públicos ou particulares.

O Estado de Direito perfaz a estruturação e a organização da Administração Pública, delimitando a competência dos órgãos e regulamentando as atividades dos agentes públicos, mediante o estabelecimento das formas de exercício de controle sobre as manifestaçôes de vontades (MEIRELLES, 2011, p. 713). Deste modo, a Administração Pública está sujeita a uma multiplicidade de controle para atingir os propósitos da missão estatal - atender ao interesse público e à satisfação do bem comum. Os meios de controle regulamentados pela norma jurídica objetivam a prevenção e a revisáo de condutas revestidas de ilegalidades praticadas pelos agentes públicos no exercício de suas funçôes administrativas (MELLO, 2014, p. 953).

Os meios fiscalizatórios dos bens e da aplicação dos recursos públicos são instrumentos com previsão constitucional que objetivam apreciar a legalidade/ regularidade dos atos dos agentes estatais e os respectivos resultados de acordo com a legalidade, moralidade, economicidade e a eficiência, mediante a análise do custo-benefício e do atendimento do interesse público. Os mecanismos de controle buscam evitar que os agentes públicos utilizem das prerrogativas do cargo e dos poderes das funçóes para satisfazer seus interesses particulares e para obter vantagens de forma indevida.

O artigo $37 \mathrm{CF} / 88$ estabelece deveres normativos aos agentes públicos com a observância dos princípios da legalidade, impessoalidade, moralidade, publicidade e eficiência nos atos praticados perante a Administração Pública direta e indireta, ou seja, a norma constitucional atribui um dever aos agentes públicos de atuar em conformidade com a legalidade, impessoalidade, moralidade, publicidade e eficiência. Os princípios da Administração Pública delimitam a forma de atuação do agente, assim como estabelecem deveres normativos de atuaçáo como condição de validade e eficácia dos atos administrativos.

O artigo 15 da Declaração dos Direitos do Homem e do Cidadão prevê que a sociedade tem o direito de pedir prestação de contas a todos os agentes públicos quando a sua administração, ou seja, trata-se de mandamentos políticos ou declaraçôes náo vinculantes ao Estado para providenciar a instituição de mecanismos de controle perante a Administração Pública com o intuito de evitar os abusos e de justificar as decisôes tomadas pelo poder público. 
As ilegalidades perpetradas pelos agentes públicos revestidas com desvios de finalidade e abusos de poder estão submetidas ao controle - interno ou externo - da Administraçáo Pública, conforme o princípio da legalidade. A finalidade é prevenir e revisar os atos eivados de nulidade e que são lesivos à moralidade e ao patrimônio do Estado.

O controle representa uma prerrogativa de um órgão oficial e da sociedade de realizar o exame, a fiscalização e a avaliação dos atos praticados pelos agentes públicos. No Brasil, o controle da Administração Pública está assentado nos princípios do regime republicano e da separação dos poderes (Legislativo, Executivo e Judiciário), os quais formam um conjunto de sistemas de controle desempenhado por diversos órgãos e instituiçóes.

O controle da Administração Pública, portanto, é um instrumento conferido pela ordem jurídica para averiguar a compatibilidade/adequação do ato administrativo e da atuação do agente público em conformidade com os princípios do regime jurídico administrativo - legalidade, impessoalidade, moralidade, publicidade, finalidade, motivação, razoabilidade, proporcionalidade, eficiência e supremacia e indisponibilidade do interesse público e eficiência - bem como para revisar os atos administrativos ilegais e lesivos praticados pelos agentes públicos com desvio de finalidade e abuso de poder. ${ }^{4}$

\footnotetext{
${ }^{4}$ O controle da Administraçáo Pública é definido pela doutrina como conjunto de mecanismos e a prerrogativa outorgada aos poderes do Estado para fiscalização e revisão dos atos administrativos. Segundo Hely Lopes Meirelles, o controle na Administração Pública representa a faculdade de realizar a vigilância, orientação e correção que um poder, órgão ou autoridade pública exerce sobre a conduta funcional de outro (MEIRELLES, 2011, p. 713). De acordo com Maria Sylvia Zanella Di Pietro, o controle traduz-se no poder-dever dos órgãos atribuídos pela lei para realizar a fiscalização e a correção de atos ilegais inconvenientes e inoportunos, ou seja, o controle da Administração Pública representa o poder de fiscalização e de correção que exercem os órgãos dos poderes Judiciário, Legislativo e Executivo, com a finalidade de assegurar a conformidade da atuação da Administração Pública com os princípios da legalidade, moralidade, finalidade pública, publicidade, motivação e impessoalidade (DI PIETRO, 2011, p. 737). Por sua vez, Odete Medauar observa que o controle da Administração Pública corresponde à verificação de adequabilidade da atuação administrativa de acordo com as regras e os princípios previstos na ordem jurídica, isto é, representa um conjunto de mecanismos atribuídos pelo ordenamento jurídico para verificação da correspondência da regularidade e do desempenho da atividade realizada pela Administração Pública às normas jurídicas que disciplinam os comportamentos e o desempenho do poder público e de seus respectivos agentes (MEDAUAR, 2012, p. 22). Por fim, José dos Santos Carvalho Filho entende que o controle da Administração Pública representa o conjunto de mecanismos jurídicos e administrativos que outorga poderes de fiscalizaçáo e de revisão das atividades administrativas, em qualquer das esferas do poder estatal (CARVALHO FILHO, 2012, p. 941).
} 
Os elementos de controle da Administração Pública estão representados pelos atos de fiscalização e de revisão, pois objetiva não só a verificação da adequação do ato à norma jurídica, como também a revisão dos atos administrativos ilegais. $\mathrm{O}$ poder de fiscalização consiste na verificaçáo sobre as atividades dos órgãos públicos, a forma de atuaçáo dos agentes e a compatibilidade do comportamento com o atendimento da finalidade pública. $\mathrm{O}$ poder de revisão representa a correção das condutas praticadas pelos agentes estatais, em razão da violaçáo das normas legais ou da necessidade de alteração de linhas políticas para melhor adequação ao interesse público (CARVALHO FILHO, 2012, p. 941).

Em suma, o controle do ato administrativo é realizado sob a seguinte ótica: a) legalidade: traduz-se na verificação de conformidade entre o ato praticado pelo agente público com a norma jurídica; b) gestão e eficiência: consiste na averiguação do desempenho da gestão pública baseada nos resultados e eficiência dos recursos e utilização dos bens públicos. A integração entre o controle de legalidade com o controle de resultados da Administração Pública é utilizada como princípio diretivo de fiscalização sobre os atos de corrupção.

Desse modo, o controle da Administração Pública são mecanismos destinados às seguintes finalidades: a) assegurar o cumprimento das normas jurídicas, da regularidade dos comportamentos dos agentes públicos, da correta aplicação dos recursos públicos e da utilização dos bens estatais de forma eficiente; b) avaliar o desempenho das atividades administrativas e dos resultados, apontando eventuais falhas e riscos como forma de prevenção futura; c) revisar os atos administrativos abusivos e ilegais praticados pelos agentes públicos com o objetivo de fazer sua adequação de acordo com a legislação e o interesse público.

A finalidade do controle é assegurar que a Administração Pública execute suas atividades em consonância com os princípios da legalidade, moralidade, finalidade pública, publicidade, motivação, impessoalidade, compreendendo o controle do mérito aos aspectos de discricionariedade da atuação administrativa (DI PIETRO, 2011, p. 735). A função do controle consiste em resguardar a garantia dos administrados/contribuintes diante das ilegalidades dos agentes públicos, bem como assegurar o cumprimento dos objetivos da Administração Pública - indisponibilidade do interesse público e supremacia do interesse público - para conferir legitimidade às condutas administrativas (CARVALHO FILHO, 2012, p. 942). 
Nesse aspecto, o fundamento do controle da Administração Pública encontra respaldo no princípio da legalidade e nas políticas administrativas de resultados. A legalidade dispóe que o agente público deve atuar em conformidade e nos limites estabelecidos pelo ordenamento jurídico, ou seja, as condutas praticadas devem estar subordinadas à lei. No que se refere às políticas administrativas, a Administração Pública detém a prerrogativa de estabelecer as suas próprias diretrizes, metas, prioridades e planejamento, visando ao atendimento do interesse público e à concretização da prestação dos serviços públicos de forma eficiente e racional (CARVALHO FILHO, 2012, p. 941).

Cabe ressaltar ainda que o controle do Estado está fragmentado em controle político e controle administrativo. O controle político consiste no controle exercido pelos poderes do Estado com a finalidade de preservar o equilíbrio dos poderes estatais, mediante a instituição do sistema de freios e contrapesos, para inibir o crescimento de um poder em detrimento de outro e permitir a compensação das debilidades de um não usurpar a força de outro. $\mathrm{O}$ controle administrativo representa a fiscalização realizada na Administração Pública sobre suas atividades com o objetivo de prevenir ou revisar os atos ilegais e os abusos de poder (CARVALHO FILHO, 2012, p. 939-940).

Por conseguinte, o controle tem natureza de princípio fundamental da Administração Pública, tendo em vista que o poder público está vinculado aos princípios do planejamento, coordenação, descentralizaçáo, delegação de competência e controle. $\mathrm{O}$ fundamento da natureza do controle como princípio fundamental da Administração Pública está previsto no artigo 6º do Decreto-lei no 200/67, que implica o dever de prestar contas de ações e resultados por parte dos detentores de cargos públicos. ${ }^{5}$

5 O controle dos atos da Administração Pública é um princípio jurídico fundamental, previsto no artigo $6^{\circ}$, inciso V, do Decreto-lei no 200/67. Segundo José dos Santos Carvalho Filho, a natureza jurídica do controle é a de princípio fundamental, tendo em vista que o exercício do controle é indispensável à execuçáo das atividades administrativas do Estado. A finalidade consiste em estimular os órgáos e os agentes públicos no desenvolvimento de métodos eficientes no sentido de aprimorar os sistemas de fiscalização (CARVALHO FILHO, 2012, p. 942). 
Os mecanismos preventivos de controle visam a contrabalançar os lucros de arranjos da corrupção com o preço da descoberta do ilícito, fazendo aumentar incentivos de comportamentos de integridade e de probidade. $\mathrm{O}$ fortalecimento do comportamento ético e a educação moral no poder público revigoram o compromisso do agente público com o bem comum (SPECK, 2002, p. 17).

Dessa forma, os mecanismos de controle da atuação da Administração Pública que estão previstos no ordenamento jurídico são instrumentos de fiscalização destinados à prevenção dos atos de corrupção e na revisão dos atos administrativos ilegais materializados pelos desvios de finalidade e abusos de poder, que visam a assegurar a proteção da probidade administrativa, dos direitos fundamentais e resguardar o patrimônio público e social.

\subsection{Classificação do Controle da Administração Pública Brasileira}

O controle da Administração Pública é classificado de forma didática para melhor compreensão do instituto e de visualização dos mecanismos de fiscalização e de revisão da atuação administrativa perante o sistema jurídico, especialmente sobre os órgãos e os poderes responsáveis pela fiscalização, o objeto passível de controle, a extensão e o momento em que será realizado o controle.

A classificação quanto ao órgão responsável pela execução do controle da Administração Pública é compreendida pelo controle administrativo, pelo controle legislativo e pelo controle judicial, ou seja, será exercido pelos poderes Executivo, Legislativo e Judiciário. ${ }^{6}$

O controle administrativo consiste no controle exercido pela Administração Pública sobre seus próprios atos e atividades administrativas com a finalidade de confirmar, revisar ou modificar os atos ilegais e os atos inoportunos e inconvenientes.

\footnotetext{
${ }^{6} \mathrm{Na}$ lição de Hely Lopes Meirelles, os tipos de controle exercido pelo poder público compreendem os seguintes: o controle administrativo é o controle exercido pela Administração de realizar a vigilância, orientação e a correção de um determinado poder, órgão ou autoridade pública sobre suas atividades e conduta funcional; o controle legislativo ou parlamentar é o controle do Legislativo sobre determinados atos praticado pelos poderes Executivo e Judiciário; o controle judicial é o controle exercido pelo poder Judiciário para revisão e anulação dos atos ilegais praticados pelos agentes públicos, quando lesivos ao patrimônio público ou direito individual dos administrados (MEIRELLES, 2011, p. 713).
} 
Nesse sentido, a Administração Pública poderá invalidar os atos discricionários por meio da revogação, bem como poderá anular o ato administrativo quando violar as disposiçốes legais.

O controle legislativo é o controle realizado pelo poder Legislativo sobre os atos funcionais da Administração Pública, e compreende o controle político e o controle financeiro. O controle político é a fiscalização do poder Legislativo sobre os atos ligados à função administrativa e de organização do Executivo e do Judiciário. O controle financeiro é o controle exercido pelo poder Legislativo, com o auxílio do Tribunal de Contas, sobre os poderes Executivo e Judiciário para verificação dos aspectos orçamentários (receitas e despesas) e à gestáo dos recursos públicos (CARVALHO FILHO, 2012, p. 1.002-1.003).

Por sua vez, o controle judicial representa o poder-dever de fiscalizaçáo por parte do poder Judiciário sobre os atos administrativos praticados por todos os órgãos públicos e poderes do Estado (Executivo, Legislativo e Judiciário). O controle judicial está restrito somente ao exame da legalidade do ato para verificar a adequaçáo da conduta administrativa com a norma jurídica.

A classificação quanto à extensão do controle da Administração Pública encontra-se subdividida no controle interno e no controle externo. O controle interno traduz-se na fiscalização realizada dentro do órgão da Administraçâo Pública, sobre os seus próprios atos e dos agentes que integram o órgão fiscalizador, ou seja, é o controle exercido pelos órgãos de um poder sobre as condutas administrativas produzidas dentro de sua esfera de atuação. Por outro lado, o controle externo é o controle exercido por um poder sobre os atos praticados por outro poder do Estado, isto é, representa a fiscalização exercida por um órgão que integra um poder sobre os atos praticados por outro órgáo público diverso. ${ }^{7}$

Por conseguinte, a classificação quanto ao objeto ou quanto à natureza de controle da Administração Pública está subdividida em controle de legalidade e controle de mérito do ato administrativo.

\footnotetext{
7 A distinçáo entre o controle interno e o controle externo consiste no fato de que o controle interno permite a fiscalização prévia e hierarquizada pelo próprio órgão da Administração Pública. Já o controle externo representa a verificação dos atos administrativos por órgáos públicos distintos, com respeito à independência dos poderes e à presunção de legalidade e legitimidade dos atos administrativos.
} 
O controle de legalidade é o controle exercido para verificação da adequação entre a conduta administrativa praticada pelo agente público às normas jurídicas, em que o órgáo controlador realiza a verificação da compatibilidade da conduta do agente aos preceitos legais. $\mathrm{O}$ controle da legalidade poderá ocorrer por meio do controle interno ou externo exercido pela Administração Pública, pelo poder Judiciário e pelo poder Legislativo. Em contrapartida, o controle de mérito traduz na verificação da legitimidade do ato administrativo discricionário, com a finalidade de analisar os aspectos da conveniência e oportunidade dos atos praticados pela Administração Pública. $\mathrm{O}$ controle do ato discricionário não poderá ser exercido pelo poder Judiciário em virtude da preservação do princípio da separação dos poderes, mas poderá ser revogado pela própria Administração Pública que praticou o ato. ${ }^{8}$

A classificação quanto ao momento do controle ou quanto à oportunidade em que o controle da Administração Pública é realizado encontra-se fragmentado em controle preventivo (a priori), controle concomitante e controle sucessivo (a posteriori).

No controle preventivo, o controle é realizado antes do aperfeiçoamento do ato administrativo ou exercido antes da consumação da conduta administrativa. No controle concomitante o controle é realizado durante a execução do ato administrativo, ou seja, consiste na fiscalizaçáo realizada no momento ou no andamento da atividade administrativa em concomitância com o desenvolvimento da conduta praticada pela Administraçáo Pública. O controle sucessivo representa o controle realizado depois do aperfeiçoamento e consolidação do ato administrativo; já o controle repressivo é aquele exercido pelo órgão controlador em momento posterior à prática do ato administrativo, com a finalidade de revisar as ilegalidades mediante a anulação do ato.

Dessa forma, o controle da Administração Pública poderá ser exercido pelos sistemas de controle interno ou externo, por diversos órgãos públicos ou pela sociedade (cidadão ou associaçóes), em momentos distintos - anteriores ou

8 A Súmula no 473 do Supremo Tribunal Federal prevê a possibilidade de revogação do ato administrativo discricionário: "A administraçâo pode anular seus próprios atos, quando eivados de vícios que os tornam ilegais, porque deles não se originam direitos; ou revogá-los, por motivo de conveniência ou oportunidade, respeitados os direitos adquiridos, e ressalvada, em todos os casos, a apreciação judicial". 
posteriores - à consolidação do ato administrativo, com o objetivo de verificar os aspectos da legalidade do ato, assim como para avaliar sua legitimidade e os resultados alcançados em consonância com a economicidade (custos-benefícios) e indisponibilidade do interesse público.

\subsection{Controle Externo pelo Tribunal de Contas}

A fiscalização dos aspectos contábeis, financeiro, orçamentário, operacional e patrimonial da Administração Pública brasileira são atribuições dos Tribunais de Contas, como guardiōes dos bens e dos recursos públicos. A Corte de Contas exerce o controle dos atos administrativos e de fiscalização das contas públicas para assegurar uma boa administração pública e a prestação dos serviços de qualidade e eficiente.

Os Tribunais de Contas surgiram nos países de formação latina, a partir do século 18 , sendo representado pela instituição de um órgão colegiado com o objetivo de exercer a tarefa de controle dos atos relativos às receitas e despesas da Administração Pública (CITADINI, 1995, p. 14-15). No Brasil, o Tribunal de Contas foi consagrado pela primeira vez com a promulgação da Constituição Federal de 1891, com atribuiçóes para liquidar as contas da receita e despesa conforme a legalidade do ato.

A doutrina define os Tribunais de Contas como órgãos públicos especializados que visam a auxiliar e orientar o poder Legislativo no exercício do controle externo com independência para praticar atos administrativos de controle e de fiscalização (BULOS, 2012, p. 946). Segundo José dos Santos Carvalho Filho, é um órgão público integrante do Congresso Nacional, com atribuiçôes constitucionais para auxiliar o poder Legislativo no controle externo contábil e financeiro da Administração Pública, sendo dotado de autonomia e autogoverno (CARVALHO FILHO, 2012, p. 1.006).

Os Tribunais de Contas são órgãos singulares com estrutura híbrida que combina as características dos órgãos de controle de contas de perfil judicial e independente e de órgãos com perfil auxiliar de auditoria que assessora o poder Legislativo (LOUREIRO, 2011, p. 25). Desse modo, detém a prerrogativa de 
apreciar e julgar as contas dos administradores/gestores dos recursos públicos e de auxiliar o Congresso Nacional no controle externo, na fiscalização, inspeçôes e auditorias de natureza contábil, financeira, orçamentária, operacional e patrimonial.

Em síntese, pode-se afirmar que os Tribunais de Contas são órgãos públicos que integram a estrutura do poder Legislativo, dotados de autonomia administrativa e financeira (autogoverno), com a função de realizar o controle externo por meio de inspeçôes e auditorias de natureza contábil, financeira, orçamentária, operacional e patrimonial, sobre as atividades dos poderes da República e da Administração Pública brasileira para verificação de irregularidades no aspecto da legalidade, legitimidade, economicidade, impessoalidade e eficiência/resultados. ${ }^{9}$

Vale registrar que a autonomia e o autogoverno dos Tribunais de Contas já foram reconhecidos pela Suprema Corte ao confirmar as atribuiçóes e as prerrogativas de autonomia funcional, administrativa e financeira para disciplinar sobre sua organização e seu funcionamento interno. ${ }^{10}$

No julgamento da ADI 4190 MC-REF/RJ, o Supremo Tribunal Federal ressaltou a ausência de qualquer vínculo de subordinação institucional dos Tribunais de Contas ao poder Legislativo, pois possuem, por expressa outorga constitucional, autonomia financeira, autogoverno e garantias da magistratura aos seus membros, isto é, os Tribunais de Contas não estão subordinados ao poder Legislativo e não são órgãos delegatários subalternos ou organismos de mero assessoramento técnico. Os Tribunais de Contas são órgãos auxiliares do poder Legislativo, sem subordinação

9 Como se observa, o artigo 70 da Constituição Federal ressalta que a fiscalização contábil, financeira, orçamentária, operacional e patrimonial da União e das entidades da Administração Pública sobre os aspectos da legalidade, legitimidade, eficiência e economicidade do ato administrativo, será exercida pelo Congresso Nacional com auxílio do Tribunal de Contas, mediante a realização do controle externo.

${ }^{10}$ BRASIL, Supremo Tribunal Federal. Ação Direta de Inconstitucionalidade $4421 \mathrm{MC} / \mathrm{TO}$. Relator: Min. Dias Toffoli, Brasília, julgado no dia 6 de outubro de 2010, publicado em 12 de fevereiro de 2011. 
e dependência, com competências para realizar por iniciativa própria inspeçóes e auditorias nas unidades administrativas dos poderes Legislativo, Executivo e Judiciário. ${ }^{11}$

No Brasil, os Tribunais de Contas estão presentes nas esferas federal, estadual e municipal. No plano federal, o controle externo será exercido pelo Congresso Nacional com o auxílio do Tribunal de Contas da União. No plano estadual, o controle externo será exercido pela Assembleia Legislativa com o auxílio dos Tribunais de Contas Estaduais. Na esfera municipal, o controle externo será exercido pela Câmara Municipal de Vereadores com auxílio dos Tribunais de Contas Estaduais ou pelos Conselhos de Contas dos Municípios (Tribunais de Contas dos Municípios), somente quando forem criados pelos Estados-membros da Federação.

Os Tribunais de Contas praticam atos de natureza administrativa de controle e de fiscalização sobre os atos e atividades da Administração Pública, excluindo a prática de atos de natureza legislativa e de natureza jurisdicional, ou seja, as decisões são dotadas de natureza administrativa ao apreciar, examinar e julgar as contas dos gestores responsáveis pelos recursos, bens e valores da Administração Pública. Ademais, vale ressaltar que as decisóes proferidas pela Corte de Contas não são jurisdicionais, uma vez que dizem respeito somente à regularidade das contas públicas, não imputando nenhuma responsabilidade restritiva de direitos para obstaculizar o acesso do interessado ao Judiciário com o objetivo de revisar eventuais ilegalidades.

$\mathrm{O}$ artigo $71 \mathrm{CF} / 88$ e o artigo $1^{\circ}$ da Lei no $8.443 / 92$ estabelecem várias atribuiçôes outorgadas aos Tribunais de Contas para realização do controle financeiro sobre os poderes do Estado e dos órgãos da Administração Pública ou de entidades privadas que recebam recursos públicos. $\mathrm{O}$ controle externo realizado pelo Legislativo com auxílio do Tribunal de Contas visa a averiguar a atuação do poder

${ }^{11}$ BRASIL. Supremo Tribunal Federal. Ação Direta de Inconstitucionalidade 4190 MC/RJ. Relator: Min. Celso de Mello, Brasília, julgado no dia 10 de março de 2010, publicado em 11 de junho de 2010 . 
público quanto aos aspectos da legalidade, legitimidade e economicidade do ato, ou seja, atua sobre as previsões orçamentárias, receitas, despesas, execuçáo de obras e a gestáo de recursos e dos bens públicos. ${ }^{12}$

${ }^{12}$ As atribuiçóes outorgadas ao Tribunal de Contas, no exercício do controle externo, objetivam auxiliar o Congresso Nacional sobre a fiscalizaçáo das contas, dos recursos e a utilizaçáo indevida dos bens públicos, o que implica várias espécies de controle dos atos da Administração Pública. Os tipos de controle realizado pelos Tribunais de Contas se restringem aos seguintes atos de inspeçóes e auditoria: a) Controle Contábil: a fiscalização contábil consiste na correta formalizaçáo dos registros de receitas e despesas, bem como verificar a adequaçáo do balanço contábil ao patrimônio e orçamento destinado ao órgáo público; b) Controle Financeiro: A fiscalização financeira representa o acompanhamento dos depósitos e extratos bancários, empenhos, liquidação, pagamentos, ingresso de valores, movimentaçôes financeiras, isto é, a verificação das receitas e despesas realizadas perante a Administração Pública, com a finalidade de controlar as entradas e saídas dos recursos públicos; c) Controle Orçamentário: A fiscalização orçamentária consiste no acompanhamento da execução do orçamento, fiscalização do registro nas rubricas orçamentárias, ou seja, busca verificar se os gastos e arrecadaçôes foram efetuados em conformidade com a Lei Orçamentária Anual (artigo 75 da Lei $\left.\mathrm{n}^{\circ} 4.320 / 64\right)$; d) Controle Operacional: O controle operacional consiste na observância dos procedimentos legais e adequação do ato à eficiência e economicidade, isto é, consiste na verificação do alcance das metas e dos resultados/desempenho, com a respectiva análise das formas de atuação da Administraçâo Pública estão compatíveis com a eficiência e economicidade; $e$ ) Controle Patrimonial: O controle patrimonial consiste na fiscalizaçáo sobre os bens do patrimônio público constantes de almoxarifados, estoques ou em uso pela Administração Pública. O controle patrimonial se restringe na verificação do patrimônio - ativos e passivos - do poder público. Por outro lado, o objeto da apreciação das fiscalizaçôes, inspeções e auditorias pelos Tribunais de Contas destinam-se a verificar os seguintes aspectos: a) Legalidade: $\mathrm{O}$ controle visa a verificar a legalidade dos atos administrativos, mediante o exame da compatibilidade da atividade administrativa com as normas jurídicas, ou seja, visa a examinar a adequação da atividade administrativa com os preceitos legais; b) Legitimidade: $\mathrm{O}$ controle representa a verificação da compatibilidade dos atos administrativos com os fins almejados pelo Estado e com os princípios da legalidade, impessoalidade, moralidade, eficiência e publicidade. A verificaçáo da legitimidade se reveste no exame do mérito do ato administrativo em conformidade com moralidade e a adequação quanto aos fins do Estado. c) Economicidade: O controle objetiva analisar a racionalização dos recursos e das despesas públicas para obtençáo do melhor custo-benefício de acordo com o orçamento. Na economicidade a Administraçáo Pública deverá analisar o custo-benefício das despesas públicas com a finalidade de se evitar desperdícios e o comprometimento do orçamento. d) Subvençôes: A fiscalizaçáo do emprego efetivo e adequado dos recursos públicos custeados pela Administração Pública, ou seja, consiste em verificar as transferências de recursos públicos destinadas a cobrir despesas de custeio das entidades beneficiadas (artigo 12, $\$ 3^{\circ}$, Lei 4.320/64); e) Renúncia de receitas: A fiscalização sobre as políticas de isençóes e outros estímulos ou incentivos fiscais concedidos pela Administraçāo Pública (anistia, remissōes, subsídios, créditos presumidos, diminuição de alíquota), ou seja, a verificação das renúncias de receitas depende de previsấo legal e o atendimento da indisponibilidade do interesse publico (artigo 14 da Lei Complementar no 101/00 LRF). 
A fiscalização pelo Tribunal de Contas abrange as pessoas jurídicas e físicas, públicas ou privadas, que tenha recebido recursos de origem estatal, tendo em vista que a administraçáo dos recursos públicos e o gerenciamento dos bens e valores obrigam à prestação de contas. Nos termos do artigo 70, parágrafo único, $\mathrm{CF} / 88$, é passível de controle pelo Tribunal de Contas "qualquer pessoa física ou jurídica, pública ou privada, que utilize, arrecade, guarde, gerencie ou administre dinheiros, bens e valores públicos".

Em contrapartida, os recursos privados e aqueles provenientes de exploração de atividade econômica ou da gestão de entidades privadas, resultantes dos lucros obtidos por bancos governamentais não são suscetíveis do controle pelo Tribunal de Contas, pois os valores integram o patrimônio privado da pessoa e não do Estado.

Os instrumentos de fiscalização disponibilizados aos Tribunais de Contas abrangem o acompanhamento, o monitoramento, o levantamento, a auditoria e inspeçôes, ${ }^{13}$ com o escopo de averiguar as atividades do poder público por iniciativa própria do Tribunal ou por meio de provocaçóes de terceiros decorrentes de denúncias ou representaçóes.

${ }^{13}$ Os instrumentos de fiscalização outorgados aos Tribunais de Contas são os seguintes: a) Levantamento (artigo 238 RITCU): o levantamento é o instrumento de fiscalização utilizado pelo Tribunal de Contas para tomar conhecimento sobre a organização e o funcionamento dos órgãos e entidades públicas sobre a utilizaçáo dos sistemas e programas de natureza contábil, financeira, orçamentária e patrimonial, bem como para identificar os instrumentos de fiscalização e avaliar a viabilidade da realização de fiscalizaçóes de rotina; b) Auditoria (artigo 239 RITCU): a auditoria consiste no instrumento de fiscalização utilizado pelo Tribunal de Contas para examinar a legalidade e a legitimidade dos atos administrativos praticados pelos agentes públicos, sobre o seu aspecto contábil, financeiro, orçamentário e patrimonial, bem como para avaliar o desempenho dos órgãos e entidades públicas (sistemas operacionais, programas, projetos e atividades governamentais), em relação à economicidade, eficiência e eficácia; c) Inspeção (artigo 240 RITCU): a inspeção representa o mecanismo de fiscalização utilizado pelo Tribunal de Contas para suprir omissōes e lacunas de informaçôes, esclarecer dúvidas ou apurar denúncias ou representaçōes realizadas por terceiros, com a finalidade de verificar a legalidade, legitimidade, economicidade e eficiência dos atos administrativos praticados pelos agentes públicos; d) Acompanhamento (artigo 241 RITCU): o acompanhamento representa o instrumento de fiscalizaçáo utilizado pelo Tribunal de Contas para examinar por um período predeterminado a legalidade e a legitimidade dos atos administrativos em seu aspecto contábil, financeiro, orçamentário e patrimonial, bem como a respectiva avaliação do desempenho dos órgáos e entidades públicas em relaçáo à economicidade, eficiência e eficácia; e) Monitoramento (artigo 243 RITCU): o monitoramento é o instrumento de fiscalização utilizado pelo Tribunal de Contas para verificar o cumprimento das deliberaçóes e os resultados alcançados pela Administração Pública. 
Em suma, aos Tribunais de Contas compete julgar as contas dos administradores responsáveis pelo gerenciamento dos recursos, bens e valores da Administração Pública direta e indireta, bem como as contas dos agentes públicos que derem causa à perda, extravio ou irregularidades que resultem em dano ao Erário (artigo 71, inciso II, CF/88 e o artigo $1^{\circ}$, inciso I, da Lei no $8.443 / 92$ ).

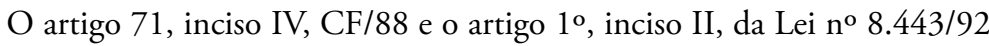
disciplina a competência do Tribunal de Contas para proceder, por iniciativa própria ou mediante solicitação/requisição de terceiros, a realização de fiscalização contábil, financeira, orçamentária, operacional e patrimonial sobre as atividades dos órgãos do poder público.

Com efeito, nos termos do artigo 71, inciso III, CF/88 e do artigo $1^{\circ}$, inciso V, da Lei no 8.443/92, a competência do Tribunal de Contas para apreciar a legalidade das atividades e dos atos praticados perante a Administração Pública direta e indireta para fins de registro. O exercício de controle de legalidade verifica a compatibilidade do ato com os dispositivos legais para evitar desvios de condutas e ilegalidades dos agentes públicos.

No mesmo sentido, o Tribunal de Contas possui a prerrogativa de representar ao órgão competente (Legislativo, Executivo, Judiciário, Ministério Público e outros órgãos públicos) a constatação de indícios de irregularidades ou abusos de poder, mediante a indicação do ato administrativo ilegal e as responsabilidades previstas no ordenamento jurídico (artigo 71, inciso XI, CF/88 e o artigo $1^{\circ}$, inciso VIII, da Lei no 8.443/92). A prévia comunicação das ilegalidades constatadas para outros órgãos públicos é indispensável para viabilizar abertura de processos investigatórios de natureza administrativa, civil e penal, bem como assegurar a punição aos funcionários públicos responsáveis pelo ato ilegal. 
Outra relevante atribuição conferida ao Tribunal de Contas consiste na prerrogativa de verificar a constitucionalidade da lei ou do ato normativo praticado pela Administração Pública, pois lhe é facultado deixar de aplicar uma lei com fundamento em sua inconstitucionalidade, desde que aprovada pela maioria dos seus membros, em respeito à cláusula de reserva de plenário. ${ }^{14}$

O Tribunal de Contas também poderá aplicar sançóes de ressarcimento ou de multa proporcional ao dano causado ao Erário, aos agentes públicos responsáveis pela ilegalidade da despesa ou irregularidade das contas (artigo 71, inciso VIII, $\mathrm{CF} / 88 \mathrm{c} / \mathrm{c}$ artigo $1^{\circ}$, inciso IX, da Lei no 8.443/92). As decisóes que resultarem na imputação de débito/ressarcimento ou de multa são dotadas de eficácia de título executivo (artigo 71, $\$ 3^{\circ}, \mathrm{CF} / 88$ ), sendo dispensável a inscrição dos débitos do ressarcimento ou da multa em dívida ativa, uma vez que a própria Constituição Federal confere eficácia executiva às decisóes dos Tribunais de Contas. A multa imposta aos responsáveis por irregularidades no uso de bens ou recursos públicos poderá ser cobrada administrativamente ou por meio de ação judicial proposta pelo ente público beneficiário da condenação proferida pelo Tribunal de Contas. ${ }^{15}$

Por fim, o artigo 71, inciso X, CF/88 e o artigo 45 da Lei no 8.443/92 preconizam que o Tribunal de Contas poderá estabelecer prazo para que o agente público responsável adote as providências necessárias para fazer o cumprimento da lei, quando constatada a ilegalidade do ato ou do contrato administrativo. Náo havendo atendimento ao pedido, poderá ocorrer a sustação da execução do ato objeto de impugnação ou aplicação de sanções de multa aos responsáveis pelas ilegalidades.

Vale ressaltar, todavia, que o Tribunal de Contas náo possui poder para declarar a anulaçáo ou a suspensão do contrato administrativo celebrado pelo poder público, mas tem a prerrogativa para notificar a autoridade administrativa

${ }^{14} \mathrm{O}$ controle de constitucionalidade incidental exercido pelos Tribunais de Contas encontra fundamento na Súmula 347 do Supremo Tribunal Federal, conforme dispóe: "O Tribunal de Contas, no exercício de suas atribuiçôes, pode apreciar a constitucionalidade das leis e dos atos do poder público."

${ }^{15}$ BRASIL. Supremo Tribunal Federal. Agravo Regimental em Recurso Extraordinário 510.034/AC. Relator: Min. Eros Grau, Segunda Turma, Brasília, julgado no dia 24 de junho de 2008, publicado em 15 de agosto de 2008 . 
determinando que promova a anulação do contrato administrativo e da licitação de que se originou, em observância ao princípio da autotutela, sob pena de imposição de sanções de aplicação de multa ou de ressarcimento ao erário. ${ }^{16}$

Por sua vez, o Tribunal de Contas, no exercício de suas funçóes fiscalizatórias das contas públicas, não possui legitimidade para decretação do sigilo bancário para apurar os indícios de irregularidades. O Supremo Tribunal Federal, no Mandado de Segurança 22934/DF pronunciou-se sobre a ilegitimidade do Tribunal de Contas para ordenar a decretação da quebra do sigilo de dados bancários ou requisitar informaçóes que importem em quebra de sigilo bancário, uma vez que a Lei Complementar ${ }^{\circ}$ 105/01 não conferiu o poder de decretação do sigilo bancário à Corte de Contas. ${ }^{17}$

Do mesmo modo, no julgamento do Mandado de Segurança 22.801/DF, a Suprema Corte também entendeu que o Tribunal de Contas da União não detém poderes para determinar a quebra do sigilo bancário de dados constantes do Banco Central do Brasil, tendo em vista que o legislador conferiu a prerrogativa da quebra de sigilo ao poder Judiciário mediante decisão fundamentada e ao poder Legislativo Federal e às Comissóes Parlamentares de Inquérito, após prévia aprovação do pedido pelo Plenário da Câmara dos Deputados, do Senado Federal ou do plenário de suas respectivas Comissōes Parlamentares de Inquérito. ${ }^{18}$

O artigo 44, $\$ 2^{\circ}$, da Lei $n^{\circ} 8.443 / 92$, ressalta que o Tribunal de Contas poderá, de forma cautelar, determinar o afastamento temporário do responsável, bem como decretar a indisponibilidade de seus bens, por prazo não superior a um ano, com o objetivo de garantir o ressarcimento dos danos em apuraçáo e a utilidade das deliberações finais. Em que pese a Constituição Federal não ter disciplinado a respeito, de forma tácita, outorga aos Tribunais de Contas a competência de determinarem o afastamento temporário das funçôes e decretar a indisponibilidade dos bens do(s) agente(s) público(s) envolvidos nos atos de corrupção, com fundamento

\footnotetext{
${ }^{16}$ BRASIL. Supremo Tribunal Federal. Mandado de Segurança 23.550/DF. Relator: Min. Marco Aurélio, Tribunal Pleno, Brasília, julgado no dia 4 de abril de 2001, publicado em 31 de outubro de 2001.

${ }^{17}$ BRASIL. Supremo Tribunal Federal. Mandado de Segurança 22.934/DF. Relator: Min. Joaquim Barbosa, Brasília, julgado no dia 17 de abril de 2012, publicado em 9 de maio de 2012.

${ }^{18}$ BRASIL. Supremo Tribunal Federal. Mandado de Segurança 22.801/DF. Relator: Min. Menezes Direito, Brasília, julgado no dia 17 de dezembro de 2007, publicado em 14 de março de 2008.
} 
nos poderes gerais de cautela e sua compatibilidade com o sistema de controle externo - inspeçóes e auditorias de natureza contábil, financeira, orçamentária, operacional e patrimonial - sobre as contas públicas.

No Mandado de Segurança 24510/DF, o Supremo Tribunal Federal também reconheceu a competência do Tribunal de Contas da União para fiscalizar procedimentos licitatórios, determinar suspensão cautelar, examinar os editais publicados e legitimidade para expedição de medidas cautelares para prevenir lesão ao Erário e garantir a efetividade das decisóes, nos termos do artigo 276 do Regimento Interno do Tribunal de Contas da União. ${ }^{19}$ Do mesmo modo, o ministro Celso de Mello, ao julgar a Medida Cautelar em Mandado de Segurança 26.547/DF, ressaltou o poder geral de cautela ao Tribunal de Contas para determinar recomendaçóes e adotar providências para invalidação do processo licitatório e da suspensáo do contrato administrativo que adjudicou o objeto da licitação, visando ao cumprimento da lei, prevenir eventual lesão ao erário e garantir a efetividade de suas decisóes. ${ }^{20}$

${ }^{19}$ BRASIL. Supremo Tribunal Federal. Mandado de Segurança 24.510/DF. Relatora: Min. Ellen Gracie, Brasília, julgado no dia 19 de novembro de 2003, publicado em 19 de março de 2004.

${ }^{20}$ A teoria dos poderes implícitos foi construída pela decisão histórica da Suprema Corte dos Estados Unidos da América do caso McCulloch v. Maryland, em 1819, reconhecendo a outorga de poderes implícitos ao Congresso para execução das competências expressas pela norma constitucional, com o objetivo de criar um governo funcional, ou seja, ressalta que a outorga de competência expressa pela Constituição a determinado órgão do Estado importa em deferimento implícito dos meios necessários à integral realizaçáo dos fins que lhe foram atribuídos. Por sua vez, os poderes implícitos do Tribunal de Contas são poderes gerais de cautela decorrente da prerrogativa institucional de forma implícita das atribuiçóes que a Constituição outorgou aos Tribunais de Contas. Os provimentos cautelares compóem uma das atribuiçóes do Tribunal de Contas, como instrumento vocacionado em tornar efetivas as múltiplas e relevantes competências que foram outorgadas pela norma constitucional, bem como para resguardar eventuais lesóes ao patrimônio público. Deste modo, as atribuiçóes dos poderes expressos conferidas ao Tribunal de Contas, reconhece também, de forma implícita, a possibilidade de a Corte de Contas conceder provimentos cautelares para tornar efetiva suas decisóes e neutralizar situaçóes de lesividade ao erário. $\mathrm{O}$ instrumento do poder de cautela exercido pelo Tribunal de Contas é compatível com a função do controle externo e da fiscalização financeira e orçamentária das contas públicas, que visa à regularidade das finanças estatais e prevenir eventuais lesóes ao Erário, bem como impedir o retardamento na apreciação do mérito e frustrar o resultado da deliberação final. Por tais razóes, a concessão de provimentos cautelares pela Corte de Contas, fundamentada nos pressupostos da existência de plausibilidade jurídica "fumus boni juris" e na possibilidade de lesão irreparável ou de difícil reparação "periculum in mora", não desrespeita a garantia do contraditório, tendo em vista a justificativa da situação de urgência do risco de comprometer o interesse público (evitar lesôes) ou de frustração da deliberação final (morosidade) (BRASIL, Supremo Tribunal Federal. Mandado de Segurança 26.547 MC/DF. Relator: Min. Celso de Mello, Brasília, julgado em 23 de maio de 2007, publicado em 29 de maio de 2007). 
A competência não escrita também reconhecida como competência implícita tem origem no sistema jurídico norte-americano, em que os "implied powers" são poderes atribuídos ao órgão de soberania e que não estáo expressos pela Constituição Federal, mas que estão adequados à consecução das finalidades institucionais e da realização das tarefas constitucionais, com a finalidade de densificar as competências previamente atribuídas pela norma constitucional. Por outro lado, os poderes implícitos possuem limites, haja vista que não podem subverter a separação dos poderes e a independência dos órgãos da soberania do Estado estabelecida pela Constituição, isto é, os poderes complementares derivados de uma conexão material não poderão afetar a atribuições de outros órgãos constitucionais (CANOTILHO; MOREIRA, 1991, p. 190-191).

Assim sendo, os poderes gerais de cautela outorgados aos Tribunais de Contas - determinação do afastamento das funçóes e a decretação da indisponibilidade de bens dos agentes públicos - estão inseridos implicitamente pela Constituição Federal brasileira sobre as atribuiçóes desempenhadas pelas Cortes de Contas no controle externo, ou seja, consiste na prerrogativa institucional que decorre das atribuiçôes outorgadas pela norma constitucional para seu adequado funcionamento e alcance de suas finalidades, com a obtenção do resultado útil das decisóes administrativas.

Como se depreende, as atribuiçóes outorgadas ao Tribunal de Contas, de maneira expressa ou implícita pela Constituição Federal, são indispensáveis para viabilizar o controle externo da Administração Pública brasileira, bem como visam a prevenir eventuais ocorrências de atos ilícitos perpetrados pelos agentes públicos e a dilapidação do patrimônio público para benefícios e interesses particulares.

A Corte de Contas assume papel mais efetivo na função preventiva da probidade administrativa quando realiza o monitoramento da correta aplicação dos recursos públicos, fundamentado no princípio da economicidade. As atribuiçóes constitucionais outorgadas ao órgão representam instrumentos destinados ao combate à corrupção e improbidade administrativa, pois lhe faculta tomar providências para fazer cessar as irregularidades e assegurar o cumprimento da lei (MARTINS JÚNIOR, 2009, p. 164). 
Os Tribunais de Contas, portanto, são órgãos públicos que exercem o controle externo sobre as atividades dos poderes da República e da Administração Pública brasileira, protagonizando um órgão preventivo e alternativo de resolução de conflitos no combate à corrupção, haja vista que realizam avaliaçôes, inspeçôes e auditorias para identificar os responsáveis pela malversação dos recursos públicos e de realizar o levantamento das lesóes e dos danos causadas ao erário perante a esfera administrativa.

\subsection{Controle Externo pelo Ministério Público}

O artigo 127 da Constituição Federal brasileira dispõe que o Ministério Público é uma instituição essencial à função jurisdicional do Estado que visa à defesa da ordem jurídica, do regime democrático e dos interesses sociais e individuais indisponíveis.

O Ministério Público é um órgão do Estado que integra a organização judicial brasileira, com independência funcional e autonomia administrativo-financeira, exercendo a função de defender as leis, os interesses da sociedade e do Estado Democrático de Direito. A instituição exerce relevante função social e jurídica ao executar o controle dos atos da Administração Pública, tendo em vista que as funçôes institucionais são atribuídas pela norma constitucional para defesa do patrimônio público e social.

No período romano, a instituição era designada em dois sentidos distintos, como "procuratores caesaris" do Império Romano, encarregados pela defesa dos interesses em juízo e da administração dos bens do imperador, bem como "defensor civitatis" dos romanos, responsável pelo ajuizamento de açóes contra criminosos (MEDAUAR, 2012, p. 165). Por outro lado, a maioria dos publicistas afirmam que o Ministério Público surgiu na França, a partir do século 13 (1302), por meio da edição da ordenança de Rei Felipe IV que criou a figura de Procuradores do Rei "Procurreurs de Roi", com atribuições de defender os interesses da Coroa, de assegurar a execução das ordens/leis e de desempenhar o processo acusatório inquisitivo de natureza penal (BULOS, 2012, p. 1187; MAZZILLI, 2000, p. 42-43). 
A ordem jurídica brasileira outorgou ao Ministério Público a função institucional de exercer o controle externo das atividades e dos atos da Administração Pública, por meio de açóes judiciais ou dos instrumentos extrajudiciais para defender o patrimônio público e a moralidade administrativa, com o objetivo de prevenir e reparar os atos lesivos revestidos de ilegalidade.

Vale mencionar que as funçôes institucionais designam as atividades de seu ofício, isto é, são as atribuiçôes outorgadas ao Ministério Público. Já os instrumentos de atuação representam mecanismos legais previstos na legislação pelos quais o Ministério Público poderá exercer suas funçóes no cumprimento das finalidades institucionais (MAZZILI, 2000, p. 621-622).

O Ministério Público brasileiro compreende as instituiçóes do Ministério Público da União (Federal, Trabalhista, Militar e do Distrito Federal) e o Ministério Público dos Estados. O artigo 130 da Constituiçáo Federal, todavia, prevê a figura do Ministério Público de Contas, que nada mais é do que a atuação do Ministério Público perante os Tribunais de Contas. O cargo e a carreira do Ministério Público de Contas se diferem da atuação do Ministério Público comum. O Ministério Público de Contas é um órgão especial com atuação exclusiva nos processos administrativos perante o Tribunal de Contas. De outro lado, o Ministério Público comum é uma instituição independente com atuação judicial e extrajudicial (CITADINI, 1995, p. 68).

A legislação brasileira confere várias prerrogativas aos membros do Ministério Público e instrumentos de combate à corrupção com a finalidade de cumprir a missáo institucional de defensor do patrimônio público e da moralidade administrativa, podendo exercer a fiscalização dos atos praticados pelos agentes públicos; requisitar informaçôes e documentos perante a Administração Pública direta e indireta; representar à autoridade competente (órgãos públicos) pela adoção das providências cabíveis para apurar, sanar, prevenir ou corrigir as ilegalidades ou abuso de poder praticados no exercício das funçóes públicas; apresentar proposta de termo de ajustamento de conduta com os interessados/infratores; expedir recomendaçóes ou sugestóes aos funcionários públicos para adoção de medidas no combate à corrupção em defesa da moralidade administrativa e do patrimônio público e social; promover o ajuizamento de açáo penal ou de ação civil pública para responsabilizar os agentes imputados nos atos de corrupção. 
A intervenção do Ministério Público nas atividades da Administração Pública e nos atos praticados pelo funcionário público concretiza o exercício do controle externo. A intervenção judicial ou extrajudicial deriva dos preceitos constitucionais outorgados pela norma constitucional como dever institucional: a proteção do patrimônio público e da moralidade administrativa.

Nesse sentido, Odete Medauar ressalta que a função de controle exercida pela instituição sobre os atos e omissóes do poder público encontra respaldo na Constituição Federal e nas legislaçôes infraconstitucionais. A atuação de controle extrajudicial recai sobre as autoridades, entes e órgãos públicos em todos os níveis da Federação brasileira, que resulta na adoção de medidas de instauração de inquérito civil público, emissão de recomendaçôes, expedição de relatórios e realização de termo de ajustamento de conduta com os infratores (MEDAUAR, 2012, p. 165).

Do mesmo modo, Antonio Roque Citadini explica que o Ministério Público é legitimado para exercer o controle externo perante a Administração Pública, inclusive afirma existir um vínculo de colaboraçáo entre os órgáos de controle externo da Administração Pública - Tribunais de Contas - com a instituição do Ministério Público, quando houver representação pelos órgãos de fiscalização a fim de apurar os indícios de ilegalidade constatados (CITADINI, 1995, p. 69).

Conforme exemplifica Phillip Gil França, a extensão da atividade de controle da Administração Pública pela instituição do Ministério Público está calcada na outorga legal para instauração de inquérito civil público porque exerce o papel fiscalizador da conformação da lei aos valores do Direito, ou seja, representa o operador de levantamento de informaçôes para verificação da correlação da atuação do poder público com as finalidades e determinaçóes legais (FRANÇA, 2011, p. 110-111).

Como se compreende, os membros do Ministério Público possuem prerrogativa institucional de exercer o controle externo sobre a aplicaçáo dos recursos públicos e da utilização dos bens da Administração Pública brasileira. Por outro lado, os atos ilícitos lesivos à moralidade administrativa e os danos causados ao patrimônio público, em razão das vantagens indevidas obtidas pelo funcionário público, da apropriação dos bens estatais, dos desvios e malversação dos recursos públicos, 
viabiliza o ajuizamento de açóes judiciais (cíveis e penais) para responsabilizar os agentes e reparar os danos causados ao Erário, bem como o uso de mecanismos extrajudiciais para prevenir futuros atos de corrupção.

A ordem jurídica brasileira, portanto, confere aos membros do Ministério Público poderes inerentes ao exercício do controle externo - judicial e extrajudicial - sobre as atividades da Administração Pública, antes do exaurimento ou depois da consolidação dos atos administrativos. A outorga das prerrogativas para fiscalizar, investigar e promover açóes judiciais ou medidas preventivas fortalece os meios de combate à corrupção.

As funçóes institucionais do Ministério Público devem estar direcionadas pelo zelo do interesse social ou individual indisponível, bem como pelo zelo dos interesses difusos ou coletivos. A norma constitucional elencou os principais instrumentos de atuação do Ministério Público no sentido de promover a aplicação e a execução das leis, bem como a proteção dos interesses e dos direitos coletivos, difusos e individuais indisponíveis (MAZZILLI, 2000, p. 363).

Os mecanismos extrajudiciais disponíveis e as funçôes extrajudiciais desempenhadas pelos representantes do Ministério Público são meios alternativos de resolução de conflitos, mas não exclui sua utilização como procedimento preparatório para atuação judicial (MEDAUAR, 2012, p. 165). Os instrumentos extrajudiciais são meios alternativos para evitar o ajuizamento de açóes judiciais e para buscar soluçóes rápidas e adequadas nos casos concretos.

$\mathrm{O}$ artigo 129, inciso III, CF/88 assegura a competência do Ministério Público para promover inquérito civil público e ajuizamento de ação civil pública para proteção do patrimônio público e social e de outros interesses difusos e coletivos. Por sua vez, o artigo 25, inciso IV, alínea “ $b$ ”, da Lei no 8.625/93 estabelece o poder do Ministério Público em promover a instauração de inquérito civil público e o ajuizamento de ação civil pública para anulação ou declaração de nulidade de atos lesivos ao patrimônio público ou à moralidade administrativa.

O inquérito civil público é um procedimento instaurado para apuração de atos lesivos aos interesses ou direitos a cargo do Ministério Público, bem como servir para colheita de provas para viabilizar o ajuizamento de açóes civis públicas 
(instrumento extrajudicial). ${ }^{21}$ Já a ação civil pública é uma ação ajuizada pelo Ministério Público para defesa dos interesses ou dos direitos transindividuais e a respetiva responsabilização do infrator causador da lesão ou dos danos (instrumento judicial).

Segundo o artigo 6 ${ }^{\circ}$, inciso 20, da Lei Complementar no 75/93 e o artigo 27, parágrafo único, inciso IV, da Lei no 8.625/93, o Ministério Público poderá realizar emissão de recomendaçóes para melhoria dos serviços públicos e da relevância pública, bem como ao respeito dos interesses, direitos e bens cuja defesa deverá promover. As expediçôes de recomendaçôes são direcionadas aos órgãos públicos como sugestôes, sem caráter vinculativo aos destinatários, ${ }^{22}$ que visa ao aprimoramento de qualidade dos serviços públicos.

Com efeito, o artigo 6º inciso XIV, alínea "f”, da Lei Complementar no 75/93, preconiza a competência do Ministério Público em promover açóes necessárias ao exercício de suas funçôes institucionais, visando à defesa da probidade administrativa. A lei confere liberdade de atuação ao Ministério Público para adotar quaisquer mecanismos legais disponíveis para concretizar a defesa da probidade administrativa e a lisura das funçôes públicas, em observância aos princípios da Administração Pública.

$\mathrm{O}$ artigo 27, parágrafo único, inciso IV, da Lei no 8.625/93, também prevê a possibilidade de o Ministério Público promover a realização de audiências públicas para viabilizar a reuniáo e a participação da sociedade (cidadãos, especialistas, associaçóes, entre outros) em debates sobre determinado assunto polêmico e controvertido, a fim de colher opinióes das pessoas e informaçóes do objeto da discussão. Na consulta pública busca-se obter opiniáo pública de pessoas e entidades sobre determinado assunto, com manifestaçóes formalizadas em peças instrutórias.

${ }^{21} \mathrm{O}$ inquérito civil público instaurado pelos representantes do Ministério Público está regulamentado pela Resolução no 23/2007 do Conselho Nacional do Ministério Público. Para Hugo Nigro Mazzilli, o inquérito civil público é um instrumento eficaz em razão dos seguintes motivos: a) permite a redução do ajuizamento de açôes judiciais, quando houver a desnecessidade depois de efetuada as investigaçóes; b) viabiliza o ajuizamento de açôes civis com melhores condições e mais aparelhada; c) permite a realização do termo de ajustamento de conduta com os infratores (MAZZILLI, 2000, p. 383).

${ }^{22}$ Sobre os aspectos da eficácia das recomendações, quando houver recusa injustificada no atendimento ou acatamento das sugestôes por parte dos agentes responsáveis, os membros do Ministério Público poderão dispor do ajuizamento de açóes civis públicas ou de açôes penais (MAZZILLI, 2000, p. 625). 
$\mathrm{Na}$ audiência pública busca-se obter manifestaçóes orais das pessoas e entidades, bem como provocar debates em sessão pública para discussão sobre determinado assunto específico (CARVALHO FILHO, 2012, p. 984).

Do mesmo modo, o artigo 27, parágrafo único, inciso I, da Lei no 8.625/93, dispóe sobre o dever dos membros do Ministério Público de receberem notícias de irregularidades, petiçóes e reclamaçóes de qualquer natureza de terceiros ou dos órgãos públicos fiscalizadores, bem como promover as apuraçóes e tomar as providências cabíveis para soluçôes adequadas.

Por sua vez, o representante do Ministério Público, no exercício de suas atribuições institucionais, poderá requisitar a instauração de sindicâncias perante a autoridade competente dos órgãos públicos, ou seja, quando constatar ilegalidades e irregularidades praticadas por funcionários públicos, lhe é facultado promover requisiçôes para instauração de sindicâncias, a fim de apurar os fatos e aplicar as devidas cominaçóes legais (artigo 26, inciso III, da Lei no 8.625/93).

No mesmo aspecto, o artigo $5^{\circ}$, inciso I e $\$ 6^{\circ}$, da Lei $n^{\circ} 7.347 / 85$, outorga a legitimidade de o Ministério Público realizar com os interessados o compromisso de ajustamento de sua conduta às exigências legais, mediante cominação de sançôes. O termo de ajustamento de conduta ${ }^{23}$ consiste no instrumento alternativo de resoluçáo de conflito que poderá ser utilizado nos inquéritos civil público e nas açôes civis públicas, consubstanciadas em obrigaçôes de fazer e de não fazer visando à defesa do patrimônio público e social.

Segundo Hely Lopes Meirelles, o termo de ajustamento de conduta consiste em uma forma de controle sobre os atos praticados pelos agentes da Administração Pública, com a finalidade de resolver conflito de direitos transindividuais, mediante adequação às exigências legais. $\mathrm{O}$ termo de ajustamento de conduta visa a impedir

${ }^{23}$ O Termo de Ajustamento de Conduta (TAC) representa um mecanismo jurídico de solução extrajudicial de conflito utilizado para defesa de direitos transindividuais (direitos difusos, direitos coletivos, direitos individuais homogêneos). O termo de ajustamento de conduta consiste no acordo extrajudicial tomado pelos órgãos públicos ou pelo Ministério Público, em que o causador dos danos dos direitos transindividuais (difusos, coletivos e individuais homogêneos) assume o compromisso de ajustar sua conduta de acordo com a legislação, mediante cominação de sançôes pelo descumprimento voluntário da obrigação. A regulamentação perante o Ministério Público está prevista na Resolução no 87/2010 do Conselho Superior do Ministério Público Federal. 
a continuação da irregularidade, a reparação do dano e evitar ajuizamento de açóes judiciais quando forem cumpridas as obrigaçóes estabelecidas (MEIRELLES, 2011, p. 775).

Os instrumentos de atuação extrajudicial do Ministério Público, previstos pela legislação brasileira, são essenciais para prevenir as ilegalidades praticadas perante a Administração Pública e de buscar formas alternativas para combater os atos de corrupção na esfera pública. O controle preventivo extrajudicial realizado pelo Ministério Público dispensa a adoção de medidas judiciais para defesa da moralidade e do patrimônio público, podendo obter a resolução dos conflitos relacionados com os atos de corrupção de forma mais célere e eficaz.

Dessa forma, o Ministério Público brasileiro é uma instituição pública com atribuiçóes constitucionais para exercer o controle externo das atividades administrativas e dos atos praticados pelos agentes públicos em defesa da moralidade, do patrimônio público e do Estado Democrático de Direito. Os membros da instituiçáo possuem a prerrogativa funcional para realizar o controle extrajudicial como forma alternativa de resolução de conflito sob a perspectiva do combate à corrupçáo.

\subsection{Controle Externo pelo Cidadão e Sociedade Civil Organizada (controle popular)}

O poder do Estado emana do povo brasileiro, cuja legitimidade foi outorgada pela Constituição Federal para escolher os seus representantes por meio do voto e para exercer os direitos de cidadania e de participação no controle sobre as atividades da Administração Pública. O artigo 1º, parágrafo único, da Constituição Federal, dispóe que todo poder emana do povo, sendo exercido por meio de representantes eleitos ou diretamente. $\mathrm{O}$ poder do Estado brasileiro será exercido por mandatários escolhidos pelo voto (direto e secreto) e indicados por partidos políticos (artigo $2^{\circ}$ da Lei no 4.737/65).

Os administradores poderão não só escolher seus representantes para defender os interesses da coletividade, como também realizar a fiscalização dos recursos públicos e dos bens pertencentes à Administração Pública, mediante representaçóes 
ou solicitaçôes perante os órgãos competentes, inclusive questionar a legitimidade dos atos administrativos, com respaldo na garantia do exercício da cidadania e da democracia participativa.

A democracia participativa traduz-se na possibilidade do cidadão e da sociedade civil participarem na formação das decisōes tomadas pelo poder público e no exercício de controle dos atos administrativos da Administração Pública. Neste sentido, a democracia participativa confere ao cidadão o direito de participação na elaboração do orçamento do Estado, auxiliando na definição das prioridades para os gastos do governo, bem como outorga poderes de fiscalização da aplicação das despesas e destinação dos recursos públicos, fazendo com que se evitem os desvios de finalidades e a malversação dos recursos.

O princípio da participação popular na gestão e no controle da Administração Pública é inerente à ideia de Estado Democrático de Direito e foi reafirmado pelo artigo $1^{\circ} \mathrm{CF} / 88$. A legislação disciplina diversas formas de participação do cidadão - instituição de ouvidores perante os órgãos públicos, promoçáo de audiências e consultas públicas, criação de conselhos e de sistemas disque-denúncia - como meios de instrumentos de legitimidade do poder para fins de aproximação do Estado e da sociedade (GROTTI, 2002, p. 134-137).

As teorias sistêmicas da sociedade global revelam que a sociedade civil organizada ocupa espaço reservado à formação das demandas que se dirigem ao sistema político (input) e às quais o sistema politico tem o dever de responder (output), consubstanciada no contraste entre a quantidade e qualidade das demandas com a capacidade de as instituiçóes responderem de forma adequada e tempestiva (BOBBIO, 2005, p. 36).

A legislação brasileira contempla a possibilidade do controle do poder público pelos segmentos da sociedade. $\mathrm{O}$ controle social é um controle exógeno da Administração Pública por diversos grupos sociais que se constitui em um instrumento democrático que permite a participação dos cidadáos no processo de exercício do poder e nas tomadas de decisão pelo poder público (CARVALHO FILHO, 2012, p. 950). 
As mudanças político-ideológicas e a reorganização do Estado brasileiro com o advento da Constituiçáo Federal fizeram com que o cidadão cobrasse das autoridades públicas a correta aplicação dos recursos públicos vinculadas com o retorno adequado e eficiente em prol da sociedade e do interesse público, isto é, com açóes voltadas para o gerenciamento dos resultados e sem favorecimentos particulares, mediante a obediência do princípio da moralidade pública (CITADINI, 1995, p. 106).

O controle social está assentado nos princípios da transparência e da participação popular como fatores imprescindíveis para que os governos e os serviços públicos fiquem mais responsáveis perante os cidadáos e a sociedade, e quanto mais consolidados e reconhecidos os valores democráticos, mais intensos serão a participação popular e o controle social sobre a Administração Pública (MILESKI, 2006, p. 91).

Outrossim, o controle popular encontra fundamento na democracia participativa, uma vez que o cidadâo está legitimado para exercer a intervenção na formação, nos procedimentos e nas tomadas de decisão da Administração Pública, visando a atender às prioridades do interesse público e de toda a coletividade. A participação dos cidadãos e associaçôes nas tomadas de decisão políticas e na fiscalização dos recursos públicos são instrumentos de controle assegurados pela norma constitucional brasileira.

Conforme assinala Maria Sylvia Zanella Di Pietro sobre a importância do exercício do controle popular, embora o controle seja atribuição estatal, o administrado poderá participar e provocar procedimento de controle não apenas na proteção dos interesses individuais como na proteção dos interesses coletivos. Ademais,, a Constituição outorga aos cidadãos instrumentos de ação a serem utilizados com a finalidade de exercer a fiscalizaçáo dos atos administrativos, sendo, portanto, o controle popular, o meio mais eficaz de controle da Administração Pública (DI PIETRO, 2011, p. 735).

O controle popular está previsto na Constituição Federal ao assegurar a participação e o direito de interferir nas atividades da Administração Pública, por meio do exercício de controle dos atos administrativos quando houver indícios de ilegalidades e irregularidades lesivas ao patrimônio público e à moralidade admi- 
nistrativa. A inexistência de lei específica regulamentadora não obsta o exercício do controle realizado pelo cidadáo, mediante a comunicaçáo perante os Tribunais de Contas e o Ministério Público, bem como pelo ajuizamento de açôes judiciais de mandado de segurança ou ação popular (MEIRELLES, 2011, p. 716).

O controle popular constitui um mecanismo democrático de participação da sociedade na fiscalizaçáo das contas públicas e nas atividades administrativas com a finalidade de assegurar o cumprimento da legislação aplicada ao setor público e buscar a satisfação do bem comum. O controle popular poderá ser exercido tanto pelo cidadáo como pela sociedade civil organizada ou pelas associaçóes de Direito Privado sem fins lucrativos, com destinação exclusiva para defesa do patrimônio e da moralidade pública.

A Controladoria Geral da União define o controle social como "a participaçâo do cidadão na gestão pública, na fiscalização, no monitoramento e no controle das ações da Administração Pública" (CONTROLADORIA..., 2012, p. 16). Não obstante, o controle social traduz-se no direito subjetivo de participação dos cidadãos e da sociedade civil organizada na formação das decisões governamentais do Estado e no exercício de controle das atividades do poder público.

Ademais, o direito subjetivo do cidadão de exigir a prestação de contas dos agentes públicos, bem como o direito de participar na formação das decisôes políticas do Estado e de influir em seu julgamento para satisfazer o interesse comum de toda coletividade, encontram fundamento no controle social, insculpido nos princípios fundamentais da cidadania e da democracia participativa.

Nestes termos, Hélio Saul Mileski afirma que o controle social poderá ser exercido sobre os atos da Administraçáo Pública e sobre os aspectos de política fiscal, tendo a transparência e a participação popular como elementos fundamentais para viabilizar o controle social, a fim de proporcionar ao cidadão a efetiva participação e fiscalização dos processos orçamentários do poder público, bem como avaliar e controlar os atos dos gestores públicos (MILESKI, 2006, p. 97).

Dessa maneira, o controle social implica duplo sentido. Um está voltado para o cidadáo e outro para o poder público, conforme se verifica: a) direito do cidadão: representa o direito do cidadão de participar e influir na formaçáo das decisóes do 
poder público e de exercer o controle/fiscalização das atividades administrativas; b) garantia do Estado: o poder público tem o dever de assegurar os meios e os instrumentos para viabilizar a participação dos cidadãos com suas opiniôes, bem como o exercício do controle dos recursos públicos pelos interessados.

Destarte, o controle social poderá ser exercido tanto durante o planejamento quanto na execução das açôes do governo. No controle social do planejamento orçamentário, os cidadáos e a sociedade civil organizada participam do planejamento e da elaboraçáo do Plano Plurianual (PPA), da Lei de Diretrizes Orçamentárias (LDO) e da Lei Orçamentária Anual (LOA), por meio de reunióes para apreciação das metas e ações a serem postas em prática durante o governo, bem como deliberaçóes de escolhas das prioridades dos programas de trabalho do governo. Por sua vez, no controle social de execução das despesas e açóes do governo, os cidadãos e a sociedade civil organizada realizam a fiscalização dos recursos e da utilização dos bens públicos, bem como da verificação das atividades da Administração e dos atos praticados pelos agentes, em conformidade com a legalidade, moralidade, impessoalidade, economicidade, eficiência e com o atendimento da finalidade pública (CONTROLADORIA..., 2012, p. 18-21).

No mesmo sentido, José dos Santos Carvalho Filho assevera que o controle social será efetivado de duas formas: por meio do controle natural ou controle institucional. $\mathrm{O}$ controle natural é o controle executado diretamente pelos indivíduos que integram determinada comunidade ou por meio de associaçóes, fundaçóes, sindicatos e outras entidades do terceiro setor. Por outro lado, o controle institucional será exercido por instituiçóes ou por órgãos do poder público, instituídas para defesa dos interesses gerais da coletividade (CARVALHO FILHO, 2012, p. 951).

No ordenamento jurídico brasileiro, o controle social e a participação popular na formação das decisões políticas do Estado e no controle externo da Administração Pública estão previstos pelas seguintes espécies normativas constitucionais e infraconstitucionais: a) artigo 50, inciso XXXIV, alíneas " $a$ " e " $b$ ", CF/88; b) artigo $31, \$ 3^{\circ}, \mathrm{CF} / 88$; c) artigo $37, \$ 3^{\circ}, \mathrm{CF} / 88$; d) artigo $74, \$ 2^{\circ}, \mathrm{CF} / 88$; e) artigo $3^{\circ}$, 
inciso V, da Lei no 12.527/11; f) artigo 49 da Lei Complementar no 101/00; g) artigo $133, \$ 1^{\circ}$, da Lei $n^{\circ} 8.666 / 93$; h) artigo 40 , $\$ 4^{\circ}$, da Lei $n^{\circ} 10.257 / 01$; i) artigo 31 da Lei no 9.784/99; j) artigo $3^{\circ}$, inciso IV, da Lei no $11.445 / 07 .{ }^{24}$

As normas constitucionais e infraconstitucionais visam a disciplinar a participação popular na construção de uma Administração Pública pautada pela economicidade, moralidade, honestidade, publicidade, transparência e eficiência

${ }^{24} \mathrm{O}$ controle social sobre as atividades da Administração Pública brasileira estão disciplinados pelos seguintes dispositivos: a) $\mathrm{O}$ artigo $5^{\circ}$, inciso XXXIV, alínea " $a$ ", CF/88 assegura o exercício do direito de petiçáo aos poderes públicos em defesa de direitos ou contra ilegalidade ou abuso de poder, independentemente do pagamento de taxas (direito de petiçáo); b) $\mathrm{O}$ artigo 50, inciso XXXIV, alínea " $b$ ", $\mathrm{CF} / 88$ assegura a obtenção de certidōes em repartiçôes públicas para defesa de direitos e esclarecimento de situaçōes de interesse pessoal (direito de certidão); c) $\mathrm{O}$ artigo $31, \$ 3^{\circ}, \mathrm{CF} / 88$ preconiza que as contas dos municípios deverão ficar, anualmente, pelo prazo de 60 dias, à disposiçấo de qualquer contribuinte, para exame e apreciação, sendo facultado questionar sobre a sua legitimidade; d) $\mathrm{O}$ artigo $37, \$ 3^{\circ}, \mathrm{CF} / 88$ assegura as formas de participação do usuário na Administração Pública direta e indireta, mediante a regulação: das reclamaçōes relativas à prestação dos serviços públicos, assegurada a manutenção dos serviços de atendimento ao usuário e avaliação periódica (externa e interna) da qualidade dos serviços; do acesso dos usuários a registros administrativos e a informaçóes sobre atos de governo; da representação contra o exercício negligente ou abusivo do cargo, emprego ou função na Administração Pública; e) $\mathrm{O}$ artigo $74, \$ 2^{\circ}, \mathrm{CF} / 88$ dispóe que qualquer cidadáo é parte legítima para denunciar irregularidades e ilegalidades perante o Tribunal de Contas dos municípios; f) $\mathrm{O}$ artigo $3^{\circ}$, inciso $\mathrm{V}$, da Lei $\mathrm{n}^{\circ} 12.527 / 11$ preconiza que o acesso à informaçáo pública deve ser executado em conformidade com os princípios da Administração Pública para promover o desenvolvimento do controle social da Administração Pública; g) O artigo 49 da Lei Complementar no 101/00 (Lei de Responsabilidade Fiscal) assegura a disponibilizaçáo das contas apresentadas pelo chefe do poder Executivo, durante todo o exercício financeiro, no poder Legislativo e no órgão técnico responsável pela sua elaboração, para consulta e apreciação pelos cidadãos e instituiçóes da sociedade; h) $\mathrm{O}$ artigo $133, \$ 1^{\circ}$, da Lei no $8.666 / 93$ (Lei de Licitaçōes) dispóe que qualquer participante da licitação, ou pessoa física ou jurídica, poderá representar ao Tribunal de Contas ou aos órgãos de controle interno contra as irregularidades e ilegalidades praticadas pelos agentes públicos nos procedimentos licitatórios ou nos contratos administrativos celebrados com o poder público; i) $\mathrm{O}$ artigo $40, \$ 4^{\circ}$, da Lei $\mathrm{n}^{\circ} 10.257 / 01$ (Estatuto da Cidade) preconiza que no processo de elaboração do plano diretor e na fiscalização de sua execução serão assegurados a promoção de audiências públicas e debates com a participação da população e de associaçôes representativas dos vários segmentos da sociedade, bem como o acesso aos documentos e informaçóes do plano diretor para qualquer interessado; j) $\mathrm{O}$ artigo 31 da Lei no 9.784/99 (Processo Administrativo Federal) dispóe que o órgáo público competente, mediante despacho motivado, poderá abrir período de consulta pública para manifestaçáo de terceiros (populaçáo) quando a matéria do processo envolver assunto de interesse geral e não houver prejuízo para a parte interessada; h) $\mathrm{O}$ artigo $3^{\circ}$, inciso IV, da Lei ${ }^{\circ}$ 11.445/07 (Diretrizes Nacionais para o Saneamento Básico) prevê que os serviços de saneamento seráo prestados com base no controle social, como conjunto de mecanismos e procedimentos que garantem à sociedade informaçóes, representaçóes técnicas e participaçôes nos processos de formulação de políticas, de planejamento e de avaliação dos serviços públicos de saneamento básico. 
(resultados), com o correto gerenciamento dos recursos e bens públicos, sobretudo com o propósito de possibilitar o exercício de uma atuação moderada, sem desvios de finalidade e abuso de poder.

Desse modo, o controle popular se subdivide nos seguintes aspectos: a) participação popular por meio de provocação e representação de ilegalidade perante os órgãos públicos; b) participação popular no controle legislativo para denunciar irregularidades e ilegalidades; c) participação popular no poder Judiciário por meio do ajuizamento de açôes judiciais (MARTINS JÚNIOR, 2009, p. 316-317).

O controle social da Administração Pública, mediante a participação dos cidadãos, da coletividade e de associaçôes, tem por finalidade verificar as irregularidades e de suscitar/provocar a atuação dos órgãos oficiais do Estado destinados ao exercício de controle, para analisar os atos administrativos conforme os princípios da legalidade, moralidade, impessoalidade e economicidade (MEDAUAR, 2012, p. 176). A norma constitucional reconhece o controle popular, conferindo aos cidadãos direitos e deveres na participação das decisóes e na fiscalização da coisa pública, mediante provocaçóes do Tribunal de Contas ou do Ministério Público, que são órgãos oficiais destinados à apuração de notícias de irregularidades/ilegalidades (desvios de finalidade e abuso de poder).

No Estado Democrático de Direito o controle social possibilita a ampliação dos sistemas de controle exercido sobre as atividades da Administração Pública, auxiliando os sistemas de controle oficial (MILESKI, 2006, p. 86). Assim, o controle social desempenha o papel de atividade complementar indispensável ao controle institucional pelos órgãos de fiscalização do Estado (CONTROLADORIA..., 2012, p. 9).

De outro modo, os organismos de controle oficial - Tribunal de Contas e Ministério Público - também devem praticar ações para assegurar a participação popular e o exercício do controle social, por meio da garantia da transparência dos atos governamentais, visando a estimular a participação popular e o controle social como mecanismos aliados da função fiscalizadora (MILESKI, 2006, p. 94-95).

A participação direta do cidadão na prestação do serviço público é fundamental para conservação da democracia e para assegurar a fidelidade de outros princípios no serviço público (GROTTI, 2002, p. 140). A concretização da 
democracia participativa pela participação dos cidadãos (individuais, coletividade ou associaçôes) nas decisōes públicas governamentais confere legitimidade aos atos do poder público, haja vista que o povo exerce a soberania estatal, auxiliando na prevenção da corrupção com a exigência da correta aplicação dos recursos públicos que são arrecadados dos contribuintes.

Os trabalhos a serem desenvolvidos no combate preventivo da corrupção estáo relacionados com a demonstraçáo dos custos e dos danos da corrupção, nos mais variados segmentos da sociedade, por meio de campanhas publicitárias e debates públicos para que o fenômeno da corrupção seja percebido como um problema negativo. Em segundo lugar, consiste em vencer o fatalismo da aceitação da disseminação da corrupção em diversas áreas e regióes distintas, ou seja, tornar a corrupção um problema político sujeito a modificaçóes por meio de intervençôes do poder público e reformas administrativas (SPECK, 2002, p. 19-21).

O controle popular, portanto, é um mecanismo de controle externo que possibilita a participação de qualquer cidadão ou da sociedade civil organizada nas tomadas de decisão da Administração Pública e na fiscalização dos atos de governo, estando assegurada a prerrogativa de solicitar apuração das irregularidades perante os órgãos oficias do Estado e de obter uma resposta fundamentada.

O controle popular é meio alternativo para o combate à corrupção, tendo em vista que o cidadáo e a sociedade civil estáo legitimados para realizar o controle externo das atividades da Administração Pública, com a respectiva representação das ilegalidades praticadas pelos gestores públicos, com fundamento no princípio da cidadania e da democracia participativa.

\section{CONCLUSÃO}

Os sistemas de controle preventivo voltados para o combate à corrupção são indispensáveis para a retomada da governança e governabilidade do Estado, uma vez que se destinam à efetivaçáo da boa administraçáo pública, bem como para assegurar a proteçáo da moralidade administrativa e do patrimônio público. $\mathrm{O}$ 
controle da corrupção na Administração Pública objetiva assegurar o cumprimento das normas jurídicas por parte dos agentes públicos e de prevenir e revisar os atos administrativos revestidos de ilegalidades e qualificados pela imoralidade.

O controle da corrupçáo representa um grande marco desafiador para as instituições do Estado, tendo em vista os riscos e os efeitos negativos ocasionados pelos atos de corrupção sobre os direitos fundamentais, sobre o Regime Republicano e o Estado Democrático. Nesse sentido, a corrupção não representa apenas uma ilegalidade com alta reprovação jurídica e moral, mas também consiste num fator de injustiça social, de discriminação, de desigualdade, de pobreza e de exclusão de pessoas menos favorecidas da sociedade, assim como implica a restrição da capacidade do poder público de efetivar os direitos fundamentais individuais e sociais.

O conjunto de mecanismos jurídicos de controle busca verificar a compatibilidade dos atos praticados pelos agentes públicos com os princípios da legalidade, impessoalidade, moralidade, economicidade, publicidade e eficiência. No controle preventivo a fiscalização visa a impedir o aperfeiçoamento dos atos de corrupção, da malversação dos recursos públicos e dos danos causados ao patrimônio público na sua origem. De outro lado, no controle sucessivo, objetiva a revisão dos atos abusivos e ilegais depois de sua consolidação, com a respectiva declaraçáo da nulidade dos atos de corrupção e da condenação dos agentes ao ressarcimento do Erário, quando houver danos ao patrimônio público.

Os instrumentos de controle externo utilizados pelos Tribunais de Contas, pelo Ministério Público, pela sociedade civil organizada sáo altamente eficazes para prevenção da corrupção no setor público. A fiscalização preventiva pelas instituiçóes públicas e pela sociedade representa mecanismos legítimos e alternativos de resolução do conflito dos casos de corrupção, haja vista que visa a prevenir as ilegalidades e a obtenção de vantagens particulares antes do aperfeiçoamento do ato, bem como viabiliza o controle concomitante do ato por meio do ajuizamento de açóes judiciais.

Desse modo, os mecanismos de controle externo estão relacionados com o acesso à Justiça, tendo em vista que uma vez fracassados os mecanismos preventivos de fiscalização dos órgãos públicos ou da sociedade, não obsta o interessado de recorrer ao Judiciário para impedir a formaçáo do ato administrativo acoimado de 
ilegalidades (controle preventivo) ou de responsabilizar os agentes da corrupção e realizar a recuperação dos valores e dos bens que foram desviados em benefício particular (controle sucessivo).

Ademais, registra-se que os mecanismos preventivos de controle externo realizado pelos órgãos oficiais e desempenhados pelos cidadãos não se autoexcluem, mas representam um conjunto de sistemas de fiscalizaçáo que formam uma unidade de controle, que visa a impedir a formação estratégica dos atos de corrupção até a sua execução.

A instituição do Ministério Público poderá realizar o controle externo preventivo mediante a expedição de recomendaçóes administrativas, promoção de audiências públicas, consultas populares, instauração de inquérito civil público para apuração de irregularidades e celebração de termos de ajustamento de conduta. No controle externo repressivo, o Ministério Público poderá promover o ajuizamento de açôes civis públicas ou de açóes penais para responsabilizar o agente infrator e buscar o ressarcimento dos prejuízos causados ao Erário.

Por outro lado, o cidadáo e a sociedade civil organizada também poderão realizar o controle externo preventivo por meio da participação em audiências públicas, consultas populares ou na participação da fiscalizaçáo e julgamento das decisóes administrativas, bem como realizar o monitoramento da aplicação dos recursos públicos e de representar perante os órgãos públicos eventuais irregularidades ou ilegalidades. Em contrapartida, no controle sucessivo, poderá se valer do ajuizamento de ação popular para anular os atos lesivos ao patrimônio público e à moralidade administrativa.

Por sua vez, os Tribunais de Contas são órgãos competentes para realizar o controle externo preventivo, por intermédio da realização de auditorias e inspeçôes de natureza contábil, financeira, orçamentária, operacional e patrimonial, da elaboração de pareceres sobre consultas dos interessados, da representação de constatação de ilegalidades perante as instituições públicas, da expedição de notificação para anulação do ato ou contrato, bem como pela decretaçáo do afastamento das funçóes e da indisponibilidade dos bens dos agentes públicos. 
Em relação ao controle externo sucessivo, o Tribunal de Contas não poderá anular os vícios contidos no ato e no contrato administrativo, mas tem competência para expedir notificação ao agente público responsável que praticou o ato, determinando que promova sua revogação, inclusive podendo aplicar sançôes de multa e de ressarcimento ao Erário em caso de descumprimento.

O conjunto de medidas preventivas de controle externo, como assegurar o acesso aos documentos e informaçóes públicas (receitas, despesas, patrimônio, registros financeiros e de recursos humanos, licitação, contratos); a aplicação de testes de integridade no setor público; a comunicação de irregularidades perante os órgãos competentes; a elaboração de Códigos de Conduta no setor público para promover o compromisso com o interesse público e selar a responsabilidade do cargo público; permitir a cooperação e o diálogo de informaçóes e de dados perante dos órgáos de fiscalização, são indispensáveis para evitar os prejuízos causados pelo fenômeno da corrupção e de modificar o modo de atuação para promover a moralidade e de resguardar o patrimônio público social.

Dessa forma, o emprego do controle preventivo externo desempenhado pelos órgãos públicos, pelos cidadáos e sociedade civil organizada, por meio do manejamento dos mecanismos/instrumentos de fiscalização previstos no ordenamento jurídico sobre as atividades da Administração Pública, são mais eficazes do que o uso de açôes judiciais, haja vista que impede a formação e a consolidação dos atos de corrupção e inviabiliza a dilapidação do patrimônio público em benefício particular.

\section{REFERÊNCIAS}

BOBBIO, Norberto. Estado, governo, sociedade: para uma teoria geral da política. 12. ed. Rio de Janeiro: Paz e Terra, 2005.

BRASIL. Supremo Tribunal Federal. Ação Direta de Inconstitucionalidade 4190 MC/RJ. Relator: Min. Celso de Mello, Brasília, julgado no dia 10 de março de 2010, publicado em 11 de junho de 2010. Disponível em: <http://redir.stf.jus.br/paginadorpub/paginador. jsp?docTP=AC\&docID=612217>. Acesso em 19 nov. 2015. 
Supremo Tribunal Federal. Ação Direta de Inconstitucionalidade $4421 \mathrm{MC} / T O$. Relator: Min. Dias Toffoli, Brasília, julgado no dia 6 de outubro de 2010, publicado em 12 de fevereiro de 2011. Disponível em: <http://redir.stf.jus.br/paginadorpub/paginador. jsp?docTP=TP\&docID=1237567>. Acesso em: 20 nov. 2015.

. Supremo Tribunal Federal. Agravo Regimental em Recurso Extraordinário 510.034/ AC. Relator: Min. Eros Grau, Segunda Turma, Brasília, julgado no dia 24 de junho de 2008, publicado em 15 de agosto de 2008. Disponível em: <http://redir.stf.jus.br/paginadorpub/ paginador.jsp?docTP=AC\&docID=541801>. Acesso em 7 de dezembro de 2015.

- Supremo Tribunal Federal. Mandado de Segurança 22801/DF. Relator: Min. Menezes Direito, Brasília, julgado no dia 17 de dezembro de 2007, publicado em 14 de março de 2008. Disponível em: <http://redir.stf.jus.br/paginadorpub/paginador. jsp?docTP=AC\&docID=515133>. Acesso em: 20 nov. 2015.

Supremo Tribunal Federal. Mandado de Segurança 22934/DF. Relator: Min. Joaquim Barbosa, Brasília, julgado no dia 17 de abril de 2012, publicado em 09 de maio de 2012. Disponível em: <http://redir.stf.jus.br/paginadorpub/paginador. jsp?docTP=TP\&docID=1973260>. Acesso em: 20 nov. 2015.

. Supremo Tribunal Federal. Mandado de Segurança 23550/DF. Relator: Min. Marco Aurélio, Tribunal Pleno, Brasília, julgado no dia 04 de abril de 2001, publicado em 31 de outubro de 2001. Disponível em: <http://redir.stf.jus.br/paginadorpub/paginador. jsp?docTP=AC\&docID=85979>. Acesso em: 7 dez. 2015.

. Supremo Tribunal Federal. Mandado de Segurança 24510/DF. Relatora: Min. Ellen Gracie, Brasília, julgado no dia 19 de novembro de 2003, publicado em 19 de março de 2004. Disponível em: <http://redir.stf.jus.br/paginadorpub/paginador. jsp?docTP=AC\&docID=86146>. Acesso em: 31 out. 2015.

. Supremo Tribunal Federal. Mandado de Segurança 26547 MC/DF. Relator: Min. Celso de Mello, Brasília, julgado em 23 de maio de 2007, publicado em 29 de maio de 2007. Disponível em: <http://www.stf.jus.br/portal/jurisprudencia/visualizarEmenta.asp?s 1=000056489\&base=baseMonocraticas $>$. Acesso em: 31 out. 2015.

. Tribunal de Contas da União. Regimento Interno do Tribunal de Contas da União (RITCU). Disponível em: <file://C:/Users/User/Downloads/regimento\%20(1).pdf>. Acesso em: 16 dez. 2015.

. Constituição da República Federativa do Brasil de 1988. Disponível em: <http:// www.planalto.gov.br/ccivil_03/Constituicao/Constituicao.htm>. Acesso em: 16 dez. 2015. 
Lei Complementar $n^{\circ}$ 101, de 4 de maio de 2000 (Lei de Responsabilidade Fiscal). Disponível em: <http://www.planalto.gov.br/ccivil_03/leis/LCP/Lcp101.htm>. Acesso em: 16 dez. 2015.

. Lei Complementar $n^{\circ}$ 75, de 20 de maio de 1993 (Estatuto do Ministério Público da União). Disponível em: <http://www.planalto.gov.br/ccivil_03/leis/lcp/lcp75.htm>. Acesso em: 16 dez. 2015.

Lei n 4.747, de 15 de julho de 1965 (Código Eleitoral). Disponível em: <http:// www.planalto.gov.br/ccivil_03/Leis/L4737.htm>. Acesso em: 16 dez. 2015.

. Lei $n^{\circ}$ 8.443, de 16 de julho de 1992 (Lei Orgânica do Tribunal de Contas da União). Disponível em: <http://www.planalto.gov.br/ccivil_03/Leis/L8443.htm>. Acesso em: 16 dez. 2015.

. Lei $n^{\circ}$ 8.625, de 12 de fevereiro de 1993 (Lei Orgânica Nacional do Ministério Público). Disponível em: <http://www.planalto.gov.br/ccivil_03/Leis/L8625.htm>. Acesso em: 16 dez. 2015.

. Supremo Tribunal Federal. Súmula n 347. Disponível em: <http://www.stf.jus. $\mathrm{br} /$ portal/cms/verTexto.asp?servico=jurisprudenciaSumula\&pagina=sumula_301_400>. Acesso em: 16 dez. 2015.

. Supremo Tribunal Federal. Súmula $n^{\circ}$ 473. Disponível em: <http://www.stf.jus. $\mathrm{br} /$ portal/cms/verTexto.asp?servico=jurisprudenciaSumula\&pagina=sumula_401_500>. Acesso em: 16 dez. 2015.

BULOS, Uadi Lammêgo. Constituição Federal anotada. 10. ed. São Paulo: Saraiva, 2012.

CANOTILHO, José Joaquim Gomes; MOREIRA, Vital. Fundamentos da Constituição. Coimbra: Coimbra Editora, 1991.

CARVAlHO FILHO, José dos Santos. Manual de Direito Administrativo. 25. ed. São Paulo: Atlas, 2012.

CITADINI, Antonio Roque. O controle externo da Administração Pública. São Paulo: Max Limonad, 1995.

CONTROLADORIA GERAL DA UNIÃO (CGU). Controle Social: Orientaçóes aos cidadãos para participação na gestão pública e exercício do controle social. 3. ed. Brasília, DF, 2012. (Coleção olho vivo).

DALLARI, Dalmo de Abreu. Elementos de Teoria Geral do Estado. 32. ed. São Paulo: Saraiva, 2013. 
DI PIETRO, Maria Sylvia Zanella. Direito Administrativo. 24. ed. São Paulo: Atlas, 2011. FRANÇA, Phillip Gil. O controle da administração pública: discricionariedade, tutela jurisdicional, regulação econômica e desenvolvimento. 3. ed. São Paulo: Revista dos Tribunais, 2011. FRANÇA. Declaração de Direitos do Homem e do Cidadão de 1789. Disponível em: <http:// pfdc.pgr.mpf.mp.br/atuacao-e-conteudos-de-apoio/legislacao/direitos-humanos/declar_dir_ homem_cidadao.pdf>. Acesso em: 16 dez. 2015.

GROTTI, Dinorá Adelaide Musetti. A participação popular e a consensualidade na Administração Pública. Revista de Direito Constitucional e Internacional, São Paulo, ano 10, n. 39, abr./jun. 2002.

HOUAISS, Antônio; VILLAR, Mauro de Salles. Dicionário Houaiss da Língua Portuguesa. 2a reimp. Rio de Janeiro: Objetiva, 2007.

LOUREIRO, Maria Rita Garcia (Coord.). Coordenação do Sistema de Controle da Administração Pública Federal n 33/2011. Brasília, 2011 (Série Pensando o Direito). Disponível em: <https:/www.justica.gov.br/seus-direitos/elaboracao-legislativa/pensando-o-direito/ publicacoes/anexos/33pensando_direito.pdf>. Acesso em: 17 dez. 2015.

MARINELA, Fernanda. Direito Administrativo. 5. ed. Niterói: Impetus, 2011.

MARTINS JÚNIOR, Wallace Paiva. Probidade administrativa. 4. ed. São Paulo: Saraiva, 2009.

MAZZILLI, Hugo Nigro. Regime Jurídico do Ministério Público: análise da Lei Orgânica Nacional do Ministério Público, aprovada pela Lei no 8.625, de 12 de fevereiro de 1993. 4. ed. São Paulo: Saraiva, 2000.

MEDAUAR, Odete. Controle da Administração Pública. 2. ed. São Paulo: Revista dos Tribunais, 2012.

MEIRELLES, Hely Lopes. Direito Administrativo Brasileiro. 37. ed. São Paulo: Malheiros, 2011.

MELLO, Celso Antônio Bandeira de. Curso de Direito Administrativo. 31. ed. São Paulo: Malheiros, 2014.

MICHAELIS. Dicionário Prático da Lingua Portuguesa. 2. ed. São Paulo: Melhoramentos, 2013.

MILESKI, Helio Saul. Controle social: um aliado do controle oficial. Interesse Público: Revista Bimestral de Direito Público, Porto Alegre, ano 8, n. 36, mar./abr. 2006.

SILVA, De Plácido e. Vocábulo jurídico. 31. ed. Rio de Janeiro: Forense, 2014. 
SILVA, De Plácido e; OLIVEIRA, Flávio Luis (Orgs.). Constitucionalismo, democracia, procedimento e substância. Birigui: Boreal, 2013.

SILVA, De Plácido e; RUIZ, Ivan Aparecido (Orgs.). Acesso à justiça e os direitos da personalidade. Birigui: Boreal, 2015.

SILVA, De Plácido e; FAZOLLI, Fabrício. Do direito à saúde: do paradoxo do dever público e da iniciativa privada. Revista Direitos Sociais e Políticas Públicas-Unifafibe. v. 2, n. 2, 2014. SPECK, Bruno Wilhelm. Caminhos para a transparência. In: SPECK, Bruno Wilhelm (Org.). Caminhos para a transparência: análise dois componentes de um sistema nacional de integridade. São Paulo: Unicamp, 2002. 